\title{
INTERNATIONAL CURRENCY PORTFOLIOS
}

\author{
Michael Kumhof, International Monetary Fund*
}

July 15, 2009

\begin{abstract}
The paper develops a theory that endogenizes the currency composition of international nominal bond portfolios in general equilibrium. It emphasizes the critical roles of government debt and of government policies, and thereby reconnects to the partial equilibrium portfolio balance literature of the 1980s. Consistent with recent empirical findings, optimal private sector foreign currency positions are found to be small and possibly negative, with their size decreasing in exchange rate volatility. Optimal private sector domestic currency positions are large and increasing in domestic interest rates. Uncovered interest parity is replaced by a relationship that also depends on outstanding bond stocks.
\end{abstract}

Keywords: Portfolio balance theory; imperfect asset substitutability; interest parity; open market operations.

JEL Classification: E42, F41.

The views expressed here are those of the author, and do not necessarily reflect the position of the International Monetary Fund or any other institution with which the author is affiliated. The author thanks Paul Evans, Philip Lane, Gian-Maria Milesi-Ferretti, Ken Singleton, and seminar participants at Ohio State University, the International Monetary Fund, and INFINITI Dublin 2009 for many helpful comments.

* Modeling Unit, Research Department, International Monetary Fund, 700 19th Street NW, Washington, DC 20431. E-mail: mkumhof@imf.org. 


\section{Introduction}

This paper develops a general equilibrium theory of international currency portfolios, with an emphasis on the critical roles of government debt and of government policies. It thereby reconnects with the portfolio balance literature of the 1980s, which has since been criticized for its partial equilibrium nature. The paper shows that, under more plausible assumptions about fiscal policy than have hitherto been considered in the literature, the currency composition of international nominal bond portfolios, which have a very large government bond component, remains determinate even in a full general equilibrium model. In other words, bonds denominated in different currencies become imperfect substitutes, so that the relationship between their rates of return is not correctly described by an arbitrage relationship but instead also depends on outstanding bond stocks. The model economy features two countries, two goods, two capital stocks, two monies, and two currency denominations of internationally traded bonds.

The theory has important implications for monetary policy. It implies that monetary policy can affect not only the level of inflation via a target path for the nominal anchor, but also, separately, interest rates via balance sheet operations. Balance sheet operations and interest rate changes in turn affect real allocations through their effects on relative prices and on aggregate household wealth.

The paper finds that optimal private sector foreign currency positions are small and possibly negative, with their size decreasing in exchange rate volatility. Optimal private sector domestic currency positions are large and increasing in domestic interest rates. The valuation effects of unsterilized open market bond sales are positive if the country as a whole has a negative exposure to foreign currency.

The portfolio balance theory developed in the 1980s includes Henderson and Rogoff (1982), Kouri (1983), and Branson and Henderson (1985). ${ }^{1}$ Unlike the more recent

1 This theory was recently also used by Blanchard, Giavazzi and Sa (2005). 
literature on international portfolios, this literature stressed the central role of crossborder holdings of nominal government debt. But at the same time its models did not incorporate the government's budget constraint. Obstfeld and Rogoff (1996) could therefore dismiss portfolio balance theory as partial equilibrium reasoning. This point is made most comprehensively in an important paper by Backus and Kehoe (1989) on sterilized foreign exchange intervention. ${ }^{2}$ Using only an arbitrage condition, they show that under complete asset markets, or under incomplete asset markets and a set of spanning conditions, changes in the currency composition of government debt require no offsetting changes in monetary and fiscal policies to satisfy both the government's and households' budget constraints. Consequently this 'strong form' of intervention is irrelevant for equilibrium allocations and prices. 'Weak form' intervention in asset markets generally does require offsetting changes in monetary and fiscal policies to meet the government budget constraint, but their impact can as easily be attributed to these monetary and fiscal changes as to the intervention per se. Intervention is therefore not an independent policy instrument.

This is a powerful theoretical argument. But to obtain it one needs to make the very strong assumption that arbitrary monetary and fiscal policies are available following asset market interventions, while in practice these policies are much more likely to either be exogenous or to follow rules that are completely independent of interventions. Our paper represents an exploration of such rules. This exercise can be interpreted as imposing additional constraints on the form of 'weak form' interventions. We can then ask how asset market interventions affect equilibrium allocations and prices conditional on the form of these rules. Specifically, we ask whether intervention can be effective as a second independent instrument of monetary policy, taking as given a monetary rule for the nominal anchor and a set of fiscal policy rules.

Grinols and Turnovsky $(1994)^{3}$ ask a similar question. In a small open economy model

2 The argument also applies to unsterilized intervention, which in a conventional setting should only affect the levels of prices and the nominal exchange rate but not interest rates and allocations. See Sargent and Smith (1988) on the irrelevance of open market operations in foreign currencies.

3 See also Obstfeld (1982). 
with domestic and foreign government debt and domestic money they show that while stochastic money growth appears to give rise to currency risk in partial equilibrium, this disappears once the fiscal use of stochastic seigniorage has been accounted for. The latter consists of lump-sum transfers of all stochastic seigniorage revenue back to households. This policy fully hedges households against currency risk in general equilibrium. Therefore, despite volatile exchange rates, there is no imperfect asset substitutability, a version of uncovered interest parity holds, and government asset market interventions have no effects on equilibria.

The specification of fiscal policy as lump-sum transfers, together with the small open economy assumption, is critical for this result. It is however extreme as a description of real world fiscal policy. We therefore replace it with a set of three alternative and, we would argue, more realistic assumptions.

First, we introduce fiscal spending shocks that are exogenous in that they are not automatically financed by offsetting tax changes, but that instead induce price level movements that revalue the government's nominal liabilities. With such shocks domestic currency bonds become imperfect substitutes for other asset classes because their underlying real return characteristics are different in a way that cannot be hedged. This assumption is motivated by the evidence presented in Click (1998), which strongly suggests that such shocks are an important feature of the data. He finds, in a large cross-section of countries, that most permanent government spending is financed by conventional tax revenue while transitory government spending is financed mainly by seigniorage. The main role of fiscal spending shocks in our model is to make domestic nominal bonds imperfect substitutes for domestic physical capital.

Second, we assume that shocks that originate abroad, and that affect the government's balance sheet, are allowed to change the government's net foreign asset position rather than leading to price level or tax changes. As we will show, this assumption supports the previous one by allowing for a fiscal channel for price level and exchange rate determination in a 
general equilibrium open economy setting. This is significant because, as shown by Dupor (2000) and Daniel (2001), the conventional fiscal theory of the price level breaks down in a two-country world where both governments' primary surpluses are exogenous, as long as exponentially increasing inter-governmental debts are ruled out (Bergin (2000)).

Third, we assume that lump-sum transfers are asymmetric in that the domestic government only compensates domestic agents but not foreigners for their losses on domestic currency assets. This is clearly a very plausible description of real world fiscal policy. And it is critical for our results because it is the main reason for the imperfect substitutability between domestic and foreign currency bonds, and therefore for our results on optimal portfolio non-diversification among nominal assets of different currencies.

Our model generates theoretical predictions regarding the existence and properties of international currency portfolios, and regarding their dependence on key structural characteristics. We use available empirical evidence and sensitivity analysis to support our key modeling choices. But the more fundamental empirical question concerns the availability of econometric evidence for the existence of a portfolio channel in the determination of interest rates and exchange rates. This literature is surveyed in Sarno and Taylor (2001), who conclude that studies done in the 1990s, a key one being Dominguez and Frankel (1993), have been generally supportive of a portfolio channel. But they typically find a quantitatively small effect of asset stocks on risk premia. This however does not make portfolio balance models uninteresting, for a number of reasons. First, one has to be careful in interpreting studies whose estimating equations are not derived from optimizing foundations and which therefore exhibit significant differences from the portfolio equations derived in this paper. Second, a small response of risk premia to asset stock changes is precisely what our model predicts for the large industrialized countries for which these studies have been conducted. The reason is that the sensitivity of interest differentials to asset stocks declines with the outstanding stocks of domestic currency nominal assets, which are large in industrialized countries. But this also suggests that results should be very different 
for developing countries, where very little empirical work has so far been done. Third, our most interesting result is arguably the optimality of portfolio non-diversification among different currencies. This result, which holds even when risk premia are very insensitive to asset stocks, cannot be tested by standard portfolio balance regressions. Instead it requires asset stock data by currency and by nationality of holder, which is the subject of the important recent paper by Lane and Shambaugh (2009). Their work is supportive of our results, by finding that a majority of countries has negative and/or small aggregate net foreign currency positions. $^{4}$

The recent theoretical literature has made great strides in incorporating portfolio theory into state of the art monetary dynamic general equilibrium models. Papers include Devereux and Sutherland (2006), Tille and van Wincoop (2008), Engel and Matsumoto (2009), and Coeurdacier, Kollman and Martin (2007). However, in one critical sense these papers take a different focus to the earlier portfolio balance literature. This is that they only allow agents to choose portfolios of exclusively private equity and debt. While there is sometimes a role for government in setting nominal interest rates, there is no role for government asset market operations in nominal debt, nor for government fiscal policies to affect portfolio choices. There is a reason for this choice. The key problem in this new literature is to find solution methods for portfolio equilibria, but in general there is no question as to their existence. This is because all the assets in question are either equity with idiosyncratic return characteristics, or debt whose return characteristics depend on these idiosyncratic returns. Imperfect asset substitutability is therefore a given. The problem in the older portfolio balance literature however was precisely that, for government asset market operations in nominal debt, imperfect asset substitutability could not be taken as a given. The key contributions of this paper are therefore, first, to establish conditions under which

\footnotetext{
4 Also, for the U.S., Burger and Warnock (2003) show that only around a quarter of U.S. investors' bond portfolios consists of foreign issues, of which the vast majority is in dollars. And United States Treasury (2008) shows that of the U.S. treasury securities held by foreigners, only about one third is held by the foreign private sector.
} 
imperfect asset substitutability does hold in a portfolio balance-type model, and second, to then study the determination and properties of nominal bond portfolios when the central role of government bonds in such portfolios is acknowledged.

Table 1 presents empirical evidence for this central role. It shows world debt securities as of September 2008, broken down first by domestic and international securities, and second by government, financial sector and non-financial sector issuers. ${ }^{5}$ We note that while these gross debt positions are close to net debt positions for governments and non-financial corporates, net debt positions for financial sector issuers are very much smaller because they are also major investors in debt securities of other financial sector issuers, with the difference largest in highly developed financial markets. ${ }^{6}$ Moreover, a significant share of financial sector debt is issued to finance the acquisition of government debt rather than private lending. At the world level government debt should therefore represent at least half of all debt securities available to be held, directly or through financial institutions, by households.

Our paper is of course also related to the literature on interest rate risk premia in open economy models without portfolio features. As shown in Lewis (1995), empirical risk premia have been both large in absolute value and highly variable in industrialized countries, and they are known to have been even larger in developing countries. An attempt at explaining that fact has to take into account both default and currency risk. The focus of this paper is exclusively on currency risk. ${ }^{7,8}$ Engel (1992) and Stulz (1984) show that in

\footnotetext{
5 The only securities classified by BIS as domestic are issues by residents, targeted mainly at resident investors, in domestic currency. One consequence is that all U.S. government debt securities are classified as domestic even though over $50 \%$ of them are currently held by foreigners.

6 Using national balance sheet data we computed the average share of intra-financial sector holdings among financial sector debt securities issued by euro area members Austria, Belgium, Finland, France, Greece, Italy, the Netherlands, Portugal and Spain between 2000 and 2007 at approximately one third. Even this is an understatement because it excludes holdings by the foreign financial sector. 7 There is a well-established and growing literature on default risk. The early contributions include Eaton and Gersovitz (1981) and Aizenman (1989). More recent contributions include Kletzer and Wright (2000), Kehoe and Perri (2002), Uribe and Yue (2006) and Arellano (2008). 8 Our result that the elasticity of interest rates with respect to bond stocks is decreasing in bond stocks has to be seen in this light. The common intuition that the opposite should be true comes from default risk considerations, from which we abstract.
} 
flexible price monetary models monetary volatility per se will not give rise to any currency risk premium. Engel (1999), using the frameworks of Obstfeld and Rogoff $(1998,2000)$ and Devereux and Engel (1998), shows that sticky prices are required to generate a risk premium. But the source of the risk premium in such models is the covariance of consumption and the exchange rate. This makes it difficult to rationalize large absolute-value risk premia because consumption is not very variable. ${ }^{9}$

The rest of the paper is organized as follows. Section 2 presents the model. Section 3 calibrates and computes a baseline version of the model. Section 4 discusses how the characteristics of the baseline economy vary with key parameters. Section 5 illustrates the effects of discrete government open market operations. Section 6 concludes. Mathematical details are presented in a separate Technical Appendix.

\section{The Model}

The world economy consists of two countries, Home and Foreign. Foreign variables are denoted by adding a superscript asterisk $*$ to the corresponding symbol for Home variables. Whenever the conditions characterizing Home and Foreign are symmetric, we limit our discussion to Home. Each economy is composed of a continuum of identical infinitely lived households and a government. The asset and liability structure of public and private sectors in each country is shown in Figure 1 by way of balance sheets. ${ }^{10}$ We use a continuous time stochastic monetary portfolio choice model to derive households' optimal consumption and portfolio decisions. ${ }^{11}$ Government is characterized by an initial balance sheet position and by a set of fiscal and monetary policy rules.

\footnotetext{
9 For more recent approaches see Lustig and Verdelhan (2007) and Burnside, Eichenbaum, Kleshchelski and Rebelo (2007).

10 These balance sheets anticipate one result of the paper, the fact that households short foreign currency bonds.

11 Useful surveys of the technical aspects of stochastic optimal control are contained in Chow (1979), Fleming and Rishel (1975), Malliaris and Brock (1982), Karatzas and Shreve (1991), and Duffie (1996). The seminal papers using this technique to analyze macroeconomic portfolio selection are Merton $(1969,1971)$ and Cox, Ingersoll and Ross (1985).
} 


\subsection{Uncertainty}

\subsubsection{Exogenous Processes}

There are two sources of risk in each economy, shocks to the nominal money supply and shocks to government spending. We define a two-dimensional Brownian motion $W_{t}=$ $\left[\begin{array}{ll}W_{t}^{M} & W_{t}^{M^{*}}\end{array}\right]^{\prime}$ consisting of the two shocks to the growth rates of nominal money supplies $d M_{t}$ and $d M_{t}^{*}$, and a two-dimensional Brownian motion $V_{t}=\left[\begin{array}{ll}V_{t}^{G} & V_{t}^{G^{*}}\end{array}\right]^{\prime}$ consisting of the two shocks to exogenous government spending $d G_{t}$ and $d G_{t}^{*}$. Finally we let $X_{t}=\left[\begin{array}{ll}W_{t}^{\prime} & V_{t}^{\prime}\end{array}\right]^{\prime}$. Wherever possible we will describe stochastic processes in terms of this four-dimensional process, but for some of our key results the distinction between monetary and fiscal shocks is critical, and in those cases the distinction is maintained in the notation.

Money Supply Shocks The nominal money supply follows a geometric Brownian motion with a drift process $\mu_{t}$ determined by the nominal anchor or inflation target of monetary policy. The vector of monetary diffusion terms is given by $\sigma_{M, t}^{m}=\left[\begin{array}{cc}\sigma_{M}^{M} & \sigma_{M, t}^{M^{*}}\end{array}\right]$. The first term $\sigma_{M}^{M}\left(\sigma_{M^{*}}^{M^{*}}\right.$ for the Foreign money supply process) is an exogenous and constant diffusion that multiplies shocks to the domestic money supply, while diffusions with respect to foreign money supply shocks are endogenous. The vector of fiscal diffusion terms is given by $\sigma_{M, t}^{g}=\left[\begin{array}{ll}\sigma_{M, t}^{G} & \sigma_{M, t}^{G^{*}}\end{array}\right]$, where both terms are endogenous. As a general rule throughout the paper, we index endogenous drift and diffusion terms by time if they represent possibly time-varying monetary policy choices, or if they are functions of such choices. Being an Itô process, $M_{t}$ is continuous, which ensures exchange rate determinacy. We have

$$
\frac{d M_{t}}{M_{t}}=\mu_{t} d t+\sigma_{M, t} d X_{t}=\mu_{t} d t+\sigma_{M, t}^{m} d W_{t}+\sigma_{M, t}^{g} d V_{t} .
$$

Fiscal Shocks Exogenous government spending is given by the Itô process ${ }^{12}$

$$
\frac{d G_{t}}{K_{t}}=\sigma_{G}^{G} d V_{t}^{G}
$$

\footnotetext{
12 A nonzero drift would affect feasible choices for the drift of the tax rate. But because this does not affect the presence or transmission mechanism of a portfolio channel, we ignore it without loss of generality.
} 
where $K_{t}$ denotes aggregate household physical capital, and $\sigma_{G}^{G}\left(\sigma_{G^{*}}^{G^{*}}\right.$ for the Foreign spending process) is the diffusion term multiplying domestic spending shocks. Fiscal spending shocks affect the resources available for private consumption. In order for this to represent a risk to households in general equilibrium, government consumption must be an imperfect substitute for private consumption. We choose the simplest and most tractable assumption under which this holds, by assuming that government spending does not enter household utility. ${ }^{13}$

\subsubsection{Endogenous Processes}

Exchange Rates The nominal exchange rate $E_{t}$, expressed as units of Home currency per unit of Foreign currency, floats. The process $E_{t}$ is endogenously determined as a function of the four exogenous stochastic processes. It follows a geometric Brownian motion with drift $\varepsilon_{t}$ and diffusion $\sigma_{E, t}$ :

$$
\frac{d E_{t}}{E_{t}}=\varepsilon_{t} d t+\sigma_{E, t} d X_{t}=\varepsilon_{t} d t+\sigma_{E, t}^{m} d W_{t}+\sigma_{E, t}^{g} d V_{t}
$$

To preserve symmetry in our presentation we use the notation $E_{t}^{*}=1 / E_{t}$ for the exchange rate of Foreign, which follows the stochastic process

$$
\frac{d E_{t}^{*}}{E_{t}^{*}}=\varepsilon_{t}^{*} d t+\sigma_{E^{*}, t} d X_{t}=\varepsilon_{t}^{*} d t+\sigma_{E^{*}, t}^{m} d W_{t}+\sigma_{E^{*}, t}^{g} d V_{t}
$$

Jensen's inequality implies that

$$
\varepsilon_{t}^{*}=-\varepsilon_{t}+\left(\sigma_{E, t}\right)^{2},
$$

and of course we also have $\sigma_{E^{*}, t}^{j}=-\sigma_{E, t}^{j}, j=M, M^{*}, G, G^{*}$.

Price Levels All goods are tradable, and purchasing power parity is assumed to hold. Households consume an aggregate that includes both Home and Foreign goods, with the Home CPI price level denoted by $P_{t}$. Home output is sold both to Home and Foreign, and the price of Home output in Home is denoted by $Q_{t}$. Like the nominal exchange rate, these price levels are endogenously determined and follow the processes

\footnotetext{
13 This assumption would not seem to require an apology, as it is still the dominant choice in dynamic business cycle models.
} 


$$
\begin{gathered}
\frac{d P_{t}}{P_{t}}=\pi_{P, t} d t+\sigma_{P, t} d X_{t}=\pi_{P, t} d t+\sigma_{P, t}^{m} d W_{t}+\sigma_{P, t}^{g} d V_{t} \\
\frac{d Q_{t}}{Q_{t}}=\pi_{Q, t} d t+\sigma_{Q, t} d X_{t}=\pi_{Q, t} d t+\sigma_{Q, t}^{m} d W_{t}+\sigma_{Q, t}^{g} d V_{t}
\end{gathered}
$$

Taxes Households are subject to a lump-sum tax $d T_{t}$ levied as a proportion of wealth $a_{t}^{c}$. This tax follows an Itô process with adapted drift process $\tau_{t}$ and diffusion process $\sigma_{T, t}^{m}$ :

$$
\frac{d T_{t}}{a_{t}^{c}}=\tau_{t} d t+\sigma_{T, t}^{m} d W_{t} .
$$

The drift and diffusion terms will be determined in equilibrium from a balanced budget requirement for the government. Note that taxes respond only to money supply shocks but not to fiscal shocks.

\subsection{Households}

Preferences The representative household has time-separable logarithmic preferences ${ }^{14}$ that depend on his expected lifetime path of a tradable goods consumption basket $\left\{c_{t}\right\}_{t=0}^{\infty}$ :

$$
\mathbb{E}_{0} \int_{0}^{\infty} e^{-\beta t} \ln \left(c_{t}\right) d t \quad, \quad 0<\beta<1
$$

where $\mathbb{E}_{0}$ is the expectation at time 0 , and $\beta$ is the rate of time preference. The consumption basket is in turn a Cobb-Douglas aggregate of Home produced tradables $c_{t}^{h}$ and Foreign produced tradables $c_{t}^{f}$,

$$
c_{t}=A\left(c_{t}^{h}\right)^{\gamma}\left(c_{t}^{f}\right)^{1-\gamma}
$$

where $A=(\gamma)^{-\gamma}(1-\gamma)^{-(1-\gamma)}$, and the parameter $\gamma$ represents home bias in consumption.

Cash Constraint Monetary portfolio choice models often introduce money into the utility function separably because this preserves the separability between portfolio and savings decisions found in Merton (1969, 1971). However, as pointed out by Feenstra (1986), without a positive cross partial between money and consumption the existence of money cannot be rationalized through transactions cost savings. We therefore use a cash constraint instead, and we show that it is still possible to obtain highly tractable analytical solutions.

\footnotetext{
14 Logarithmic preferences are commonly used in the open economy asset pricing and portfolio choice literature for their analytical tractability, see e.g. Stulz (1984, 1987) and Zapatero (1995).
} 
Specifically, consumers are required to hold real money balances equal to a multiple $1 / \alpha$ of their consumption expenditures $c_{t}$. Denoting real money balances by $m_{t}=M_{t} / P_{t}$, we have

$$
c_{t}=\alpha m_{t}
$$

The now very common treatment of the cash-in-advance constraint in the discrete time model of Lucas (1990) has two aspects, a cash requirement aspect and an in-advance aspect. Our own treatment goes back to the earlier Lucas (1982), which uses only the cash requirement aspect. This is due to the difficulty of implementing the in-advance timing conventions in a continuous-time framework. In the continuous time stochastic finance literature, Bakshi and Chen (1997) have used the same device.

Trading Household consumption $c_{t}$ is financed from a constant real return $r$ on physical Home capital $K_{t}$, and from the stochastic returns on three types of financial assets, (1) domestic currency denominated money $M_{t}$ with a zero nominal return, (2) domestic currency denominated bonds $H_{t}^{c}$ with nominal return $i_{t}^{h} d t$, and (3) foreign currency denominated bonds $F_{t}^{c}$ with nominal return $i_{t}^{f} d t$. To keep the analysis focused on the determinants of nominal bond portfolios, we assume complete home bias in equity. We denote real asset stocks by $h_{t}^{c}=H_{t}^{c} / P_{t}, f_{t}^{c}=\left(F_{t}^{c} E_{t}\right) / P_{t}, k_{t}=\left(K_{t} Q_{t}\right) / P_{t}$, and total private wealth by

$$
a_{t}^{c}=\frac{M_{t}+H_{t}^{c}+E_{t} F_{t}^{c}+Q_{t} K_{t}}{P_{t}}=m_{t}+h_{t}^{c}+f_{t}^{c}+k_{t} .
$$

Portfolio shares will be denoted by $n_{t}^{m}=\frac{m_{t}}{a_{t}^{c}}, n_{t}^{h}=\frac{h_{t}^{c}}{a_{t}^{c}}$ and $n_{t}^{f}=\frac{f_{t}^{c}}{a_{t}^{c}}$, with $n_{t}^{k}=\frac{k_{t}}{a_{t}^{c}}=$ $1-n_{t}^{m}-n_{t}^{h}-n_{t}^{f}$. We use the notation $n_{t}^{f i n}=n_{t}^{m}+n_{t}^{m}+n_{t}^{f}$, the share of financial assets in the overall portfolio.

Budget Constraint The household budget constraint is given by

$$
\begin{aligned}
d a_{t}^{c}= & a_{t}^{c}\left[n_{t}^{m} d r_{t}^{m}+n_{t}^{h} d r_{t}^{h}+n_{t}^{f} d r_{t}^{f}+\left(1-n_{t}^{m}-n_{t}^{h}-n_{t}^{f}\right) d r_{t}^{k}\right] \\
& -c_{t} d t-a_{t}^{c}\left[\tau_{t} d t+\sigma_{T, t}^{m} d W_{t}\right],
\end{aligned}
$$

where $d r_{t}^{i}$ is the real rate of return, in terms of the final consumption basket, on asset $i$. The Technical Appendix derives these returns using Itô's lemma. We denote the drift components of real asset returns by $\tilde{r}_{t}^{m}, \tilde{r}_{t}^{h}, \tilde{r}_{t}^{f}$ and $\tilde{r}_{t}^{k}$. Foreign exchange risk premia are given by 
deviations from real interest parity $\tilde{r}_{t}^{h}-\tilde{r}_{t}^{f}$. We adopt the following notation for private asset accumulation:

$$
\frac{d a_{t}^{c}}{a_{t}^{c}}=\mu_{a, t} d t+\sigma_{a, t} d X_{t}
$$

Capital Accumulation Households own and accumulate the capital stock $K_{t}$. The output $r K_{t} d t$ is consumed by Home and Foreign households, $c_{t}^{h} d t$ and $c_{t}^{h^{*}} d t$, and by the Home government, $d G_{t}$. We therefore have the following law of motion for the capital stock:

$$
d K_{t}=\left(r K_{t}-c_{t}^{h}-c_{t}^{h^{*}}\right) d t-\sigma_{G}^{G} K_{t} d V_{t}^{G} .
$$

Choice of Consumption Bundle The optimality conditions for domestic and foreign consumption goods are independent of the portfolio choice problem. They are standard and given by $q_{t} c_{t}^{h}=\gamma c_{t}$ and $e_{t} q_{t}^{*} c_{t}^{f}=(1-\gamma) c_{t}$, where $q_{t}=Q_{t} / P_{t}, q_{t}^{*}=Q_{t}^{*} / P_{t}^{*}$, and the consumption based real exchange rate is $e_{t}=\left(E_{t} P_{t}^{*}\right) / P_{t}$. The CPI price index pertaining to (10) can then be derived as

$$
P_{t}=\left(Q_{t}\right)^{\gamma}\left(E_{t} Q_{t}^{*}\right)^{1-\gamma}
$$

Portfolio Problem The household's portfolio problem is to maximize present discounted lifetime utility (9) subject to (11) and (13), by the appropriate portfolio choice $\left\{n_{t}^{m}, n_{t}^{h}, n_{t}^{f}\right\}_{t=0}^{\infty}$. We solve this problem recursively using a continuous time Bellman equation. Details are discussed in the Technical Appendix. The three first order necessary conditions contain the drift and diffusions of the tax process (8). For the final solution we therefore need a specification of fiscal policy rules, which we develop in the following subsection.

\subsection{Government}

Monetary Policy Monetary policy is characterized by two policy variables. First, primary control over the level of inflation is achieved through a target path for the nominal anchor consistent with an inflation target. In our model this is simply a target path $\left\{\mu_{t}\right\}_{t=0}^{\infty}$ for money growth in equation (1). Second, we will show that control of the volatility of inflation, and thereby indirectly of allocations, can be achieved by setting a target path for the stock 
of nominal government debt $\left\{B_{t}\right\}_{t=0}^{\infty}$, which is equivalent to setting a target path for the nominal interest rate $\left\{i_{t}^{h}\right\}_{t=0}^{\infty}{ }^{15}$

Government Assets and Liabilities In nominal terms, the government issues domestic currency money $M_{t}$ and domestic currency bonds $H_{t}^{c}+H_{t}^{c^{*}}$ (where we will show that $\left.H_{t}^{c^{*}}<0\right)$ to domestic households. It also issues domestic currency bonds $H_{t}^{g^{*}}$ to and buys foreign currency bonds $F_{t}^{g}$ from the foreign government. Domestic households determine their optimal overall holdings of domestic currency bonds $H_{t}^{c}$, and are indifferent between the shares of government bonds $H_{t}^{c}+H_{t}^{c^{*}}$ and of domestic currency loans to foreign households $-H_{t}^{c^{*}}$. We denote the total stock of nominal domestic currency government debt by $B_{t}$,

$$
B_{t}=H_{t}^{c}+H_{t}^{c^{*}}+H_{t}^{g^{*}}
$$

and its real stock of financial net wealth (this excludes discounted future tax revenue) in terms of the domestic goods basket by $a_{t}^{g}$,

$$
a_{t}^{g}=\frac{E_{t} F_{t}^{g}-M_{t}-B_{t}}{P_{t}}
$$

We also let $f_{t}^{g}=\left(F_{t}^{g} E_{t}\right) / P_{t}$ and $h_{t}^{g^{*}}=\left(H_{t}^{g^{*}} E_{t}^{*}\right) / P_{t}^{*}$. The government's flow budget constraint is

$$
\begin{aligned}
d a_{t}^{g}= & f_{t}^{g} d r_{t}^{f}+a_{t}^{c} \tau_{t} d t+a_{t}^{c} \sigma_{T, t}^{m} d W_{t}-k_{t} \sigma_{G}^{G} d V_{t}^{G} \\
& -n_{t}^{m} a_{t}^{c} d r_{t}^{m}-n_{t}^{h} a_{t}^{c} d r_{t}^{h}-e_{t} n_{t}^{h^{*}} a_{t}^{c^{*}} d r_{t}^{h}-e_{t} h_{t}^{g^{*}} d r_{t}^{h}
\end{aligned}
$$

Fiscal Policy The exogenous, spending component of fiscal policy is specified in (2) and the endogenous, lump-sum tax component in (8). We assume that fiscal policy meets four requirements. First, the expected budget balance is always zero, so that government assets $a_{t}^{g}$ follow an Ito-process without drift. This implies the following behavior for the drift of

\footnotetext{
15 With imperfect asset substitutability the policy problem can always be described as either fixing interest rates and then supplying as many bonds as the market demands at that interest rate, or as fixing the quantity of bonds and allowing the interest rate to clear the market. We have chosen the latter.
} 
the tax process $\tau_{t}$ :

$$
\begin{aligned}
a_{t}^{c} \tau_{t}= & \left(n_{t}^{m} a_{t}^{c}+n_{t}^{h} a_{t}^{c}+e_{t} n_{t}^{h^{*}} a_{t}^{c^{*}}+e_{t} h_{t}^{g^{*}}\right) \tilde{r}_{t}^{m} \\
& +\left(a_{t}^{c} n_{t}^{h}+e_{t} n_{t}^{h^{*}} a_{t}^{c^{*}}+e_{t} h_{t}^{g^{*}}\right) i_{t}^{h}-f_{t}^{g} \tilde{r}_{t}^{f} .
\end{aligned}
$$

Second, lump-sum taxes respond instantaneously to money supply shocks by exactly compensating households for the (net) losses from surprise inflation on their domestic currency nominal asset portfolio. ${ }^{16}$ This implies that the diffusions of the tax process are given by

$$
\sigma_{T, t}^{m}=-\left(n_{t}^{m}+n_{t}^{h}\right) \sigma_{P, t}^{m}
$$

Third, domestic fiscal spending shocks are exogenous, meaning that endogenous lump-sum taxes are not available to finance them. Instead, the budget balancing role in response to these shocks falls to the price level. We obtain

$$
\sigma_{P, t}^{G}=\sigma_{G}^{G}\left(\frac{n_{t}^{k}}{n_{t}^{m}+n_{t}^{h}}\right) .
$$

Fiscally induced price level volatility is increasing in the volatility of the fiscal shocks themselves $\sigma_{G}^{G}$, but it is decreasing in the amount of nominal government liabilities held in household portfolios $n_{t}^{m}+n_{t}^{h}$. This is because a larger stock of nominal liabilities that can be revalued by price level movements represents a larger base of the stochastic inflation tax. Fourth, all the remaining effects of shocks are absorbed by the government's net asset position $a_{t}^{g}$. This includes shocks to foreign fiscal spending and shocks to the government's asset and liability positions vis-à-vis foreigners. We obtain the following:

$$
d a_{t}^{g}=f_{t}^{g}\left(\sigma_{E, t}-\sigma_{P, t}\right) d X_{t}+\left(e_{t} n_{t}^{h^{*}} a_{t}^{c^{*}}+e_{t} h_{t}^{g^{*}}\right) \sigma_{P, t} d X_{t}+\left(n_{t}^{m} a_{t}^{c}+n_{t}^{h} a_{t}^{c}\right) \sigma_{P, t}^{G^{*}} d V_{t}^{G^{*}} .
$$

This fourth assumption plays a critical role because it allows for a fiscal channel in the determination of the price level and of the exchange rate in a general equilibrium two-country setting. As shown by Dupor (2000) and Daniel (2001), the conventional fiscal theory of the

\footnotetext{
16 We have also computed the case where foreign fiscal spending shocks are treated symmetrically with money supply shocks. This does not yield fundamentally different insights, and we therefore do not report the results in the paper.
} 
price level generally breaks down in two-country models when both governments' levels of spending and taxes are exogenous. Put simply, this is because a single instrument, the nominal exchange rate, cannot simultaneously ensure budget balance through nominal asset revaluation in two countries. ${ }^{17}$ As in Dupor (2000) and Daniel (2001), in our model shocks to spending are exogenous, and so is the instantaneous tax response, which equals zero. Domestic spending shocks are therefore financed instantaneously through price level jumps that imply exchange rate jumps. But the key point is that exchange rate jumps caused by foreign spending shocks do not unbalance the domestic budget. Instead they are allowed to instantaneously change the government's net asset position. While this leads to permanent and theoretically unbounded changes in government net assets $a_{t}^{g}$ according to (23), this does not violate government intertemporal budget balance, which instead requires only a transversality condition on $a_{t}^{g}$. That however continues to be satisfied because the lumpsum drift taxes $\tau_{t}$ of equation (20) are endogenous. Specifically, they ensure that the net revenue on any changes in government assets is from then onwards redistributed by way of lump-sum taxes, so that $\mathbb{E}_{t}\left[a_{t+\tau}^{g}\right]=a_{t}^{g}, \tau>0$. A fiscal theory of price level and exchange rate determination is therefore feasible, and under plausible conditions, even in a general equilibrium two-country model.

The rules (20) - (23) imply endogenous and stochastic adjustments of the two countries' foreign exchange reserves $f_{t}^{g}$ and $h_{t}^{g^{*}}$ in response to equilibrium changes in bond and money demands. However, it can be shown that these foreign exchange acquisition rules are not part of the core equations of the model, they can instead be determined recursively once the core model has been solved for a given set of state and policy variables.

Definition 1. A feasible government policy for Home is a list of stochastic processes $\left\{\mu_{t}, B_{t}, \tau_{t}, \sigma_{T, t}^{m}, a_{t}^{g}\right\}_{t=0}^{\infty}$ such that, given a list of stochastic processes $\left\{a_{t}^{c}, a_{t}^{c^{*}}, f_{t}^{g}, h_{t}^{g^{*}}\right.$,

\footnotetext{
17 Bergin (2000) points out a possible exception. He shows that equilibrium in the fiscal theory is in principle consistent with a case in which one government is willing to indefinitely purchase the exponentially growing debt of another government. But he questions the relevance of this case on political economy grounds. See also Sims (1997).
} 
$\left.e_{t}, \tilde{r}_{t}^{m}, \tilde{r}_{t}^{f}, i_{t}^{h}, \sigma_{E, t}, \sigma_{P, t}, X_{t}\right\}_{t=0}^{\infty}$, initial conditions $a_{0}^{c}, a_{0}^{c^{*}}, a_{0}^{g}$, and portfolio shares $n_{t}^{m}, n_{t}^{h}, n_{t}^{f}, n_{t}^{m^{*}}, n_{t}^{h^{*}}, n_{t}^{f^{*}}$, the conditions (20), (21), (22) and (23) are satisfied at all times.

In all our policy experiments in Sections 4 and 5 we will assume that government debt to GDP ratios are deterministic sequences, and that $\mu_{t}, \mu_{t}^{*}, \sigma_{M}^{M}, \sigma_{M^{*}}^{M^{*}}, \sigma_{G}^{G}$ and $\sigma_{G^{*}}^{G^{*}}$ are constants. This can be shown to imply that all mean returns (including $\tilde{r}_{t}^{m}, \tilde{r}_{t}^{h}, \tilde{r}_{t}^{f}$ ), as well as all endogenous price and policy drifts and diffusions (including $\sigma_{T, t}^{m}, \sigma_{E, t}, \sigma_{P, t}$ ) are functions only of these eight variables but not of the economy's state variables.

\subsection{Equilibrium and Current Account}

The economy's state variables at time $t$ are given by $a_{t}^{c}, a_{t}^{c^{*}}, K_{t}, K_{t}^{*}, M_{t}, M_{t}^{*}$ and the level of net foreign assets $\tilde{f}_{t}$, which is given by

$$
\tilde{f}_{t}=f_{t}^{g}+n_{t}^{f} a_{t}^{c}-e_{t}\left(h_{t}^{g^{*}}+n_{t}^{h^{*}} a_{t}^{c^{*}}\right)
$$

Then equilibrium is defined as follows:

Definition 2. An equilibrium is a set of exogenous stochastic processes $\left\{X_{t}\right\}_{t=0}^{\infty}$, initial conditions $a_{0}^{c}, a_{0}^{c^{*}}, K_{0}, K_{0}^{*}, M_{0}, M_{0}^{*}, \tilde{f}_{0}$, an allocation consisting of stochastic processes $\left\{c_{t}, c_{t}^{h}, c_{t}^{f}, c_{t}^{*}, c_{t}^{f^{*}}, c_{t}^{h^{*}}, K_{t}, K_{t}^{*}, M_{t}, M_{t}^{*}, H_{t}^{c}, H_{t}^{c^{*}}, H_{t}^{g^{*}}, F_{t}^{c^{*}}, F_{t}^{c}, F_{t}^{g}\right\}_{t=0}^{\infty}$, a price system consisting of stochastic processes $\left\{i_{t}^{h}, i_{t}^{f}, E_{t}, E_{t}^{*}, P_{t}, P_{t}^{*}, Q_{t}, Q_{t}^{*}\right\}_{t=0}^{\infty}$, and feasible government policies for Home and Foreign such that, given the exogenous stochastic processes, the initial conditions, the feasible government policies and the price system, the allocation solves households' problem of maximizing (9) subject to (11) and (13).

Current Account and GDP The current account is given by

$$
\begin{aligned}
& q_{t} c_{t}^{h^{*}}+\left(n_{t}^{f} a_{t}^{c}+f_{t}^{g}\right) \tilde{r}_{t}^{f} d t \\
= & e_{t} q_{t}^{*} c_{t}^{f}+e_{t}\left(n_{t}^{h^{*}} a_{t}^{c^{*}}+h_{t}^{g^{*}}\right) \tilde{r}_{t}^{h}+n_{t}^{f i n} a_{t}^{c} \mu_{a, t}+\sigma_{G}^{G} k_{t}\left(\sigma_{P, t}^{G}-\sigma_{Q, t}^{G}\right) .
\end{aligned}
$$


The left hand side shows exports and domestic net returns from holdings of foreign currency assets, while the right hand side shows imports, net returns paid to foreigners holding domestic currency assets, and net acquisitions of financial assets. ${ }^{18}$ Real GDP is given by

$$
g d p_{t}=r * k_{t} \text {. }
$$

Portfolio Optimality Conditions The derivation of the final household optimality conditions is presented in detail in the Technical Appendix. They are

$$
\begin{gathered}
c_{t}=\frac{\beta a_{t}^{c}}{\left(1+i_{t}^{h} / \alpha\right)}, \\
n_{t}^{d o m}=n_{t}^{m}+n_{t}^{h}=\frac{i_{t}^{h}-r-\pi_{Q, t}+\left(\sigma_{Q, t}\right)^{2}-n_{t}^{f}\left(\left(\sigma_{Q, t}\right)^{2}-\sigma_{E, t} \sigma_{Q, t}\right)}{\left(\sigma_{Q, t}\right)^{2}-\sigma_{P, t}^{m} \sigma_{Q, t}^{m}} \\
n_{t}^{f}=\frac{i_{t}^{f}+\varepsilon_{t}-r-\pi_{Q, t}+\left(\sigma_{Q, t}\right)^{2}-\sigma_{E, t} \sigma_{Q, t}}{\left(\sigma_{E, t}\right)^{2}+\left(\sigma_{Q, t}\right)^{2}-2 \sigma_{E, t} \sigma_{Q, t}} \\
-\frac{n_{t}^{d o m}\left(\left(\sigma_{Q, t}\right)^{2}-\sigma_{E, t} \sigma_{Q, t}+\sigma_{E, t}^{m} \sigma_{P, t}^{m}-\sigma_{P, t}^{m} \sigma_{Q, t}^{m}\right)}{\left(\sigma_{E, t}\right)^{2}+\left(\sigma_{Q, t}\right)^{2}-2 \sigma_{E, t} \sigma_{Q, t}} .
\end{gathered}
$$

Equation (27) is a standard condition in this model class. It states that consumption is proportional to wealth and, because of the cash constraint, negatively related to the nominal interest rate. The key novelty of this model is found in the general equilibrium portfolio balance equations (28) and (29), which demonstrate that the portfolio shares of domestic and foreign currency denominated assets are determinate even after taxes have been endogenized. Equilibrium Determinacy A key property of our model concerns equilibrium determinacy. As shown by Leeper (1991) and a long subsequent literature, in conventional monetary business cycle models equilibrium determinacy requires one of two sets of conditions. The first and more conventional is that monetary policy is active by aggressively fighting inflation while fiscal policy is passive by ensuring intertemporal solvency through adjustments of the primary surplus. The second is that fiscal policy is active by setting

18 The covariance term is negligible in size. 
an exogenous primary surplus while monetary policy is passive by accommodating fiscally induced inflation. In our model fiscal policy is active instantaneously in response to spending shocks, by equation (22), so that price levels can experience fiscally driven instantaneous jumps. But thereafter fiscal policy is passive in that it adjusts subsequent taxation to ensure solvency, by equation (20).

\subsection{Interpretation of the Portfolio Share Equations}

To understand the trade-off between domestic currency assets and domestic physical capital, equation (28) can be written approximately, ignoring covariance terms, as

$$
n_{t}^{\text {dom }} \simeq 1-\frac{r+\pi_{Q, t}-i_{t}^{h}}{\left(\sigma_{Q, t}\right)^{2}}-n_{t}^{f} .
$$

This shows that the share of domestic currency assets depends negatively on the risk adjusted excess return of holding domestic physical capital versus domestic currency assets, and on the share of foreign currency bonds. ${ }^{19}$ The direct effect of raising the nominal interest rate, ceteris paribus, is a lower excess return of capital and a higher desired share of domestic currency assets. This is only partly offset by the indirect effect of this higher share constituting a larger inflation tax base, which lowers the volatility of producer prices $\left(\sigma_{Q, t}\right)^{2}$. Less volatile producer prices lower the incentive to hold domestic currency assets because in terms of domestic output the value of domestic capital is predetermined at $K_{t}$ while the value of domestic currency assets $H_{t}^{c} / Q_{t}$ fluctuates with, and more importantly is convex in, the producer price. Convexity implies that less volatile prices are associated with a lower expected return. This also means that if producer prices become more volatile due to higher shock volatility, the government can afford to pay a lower nominal interest rate while placing an unchanged amount of domestic currency assets with households.

\footnotetext{
19 We can ignore portfolio shares of domestic currency assets at or above one, because this would correspond to a government debt to GDP ratio of over $2000 \%$. A realistic calibration typically is in the neighborhood of $n_{t}^{d o m} \simeq 0.02$.
} 
The trade-off between domestic and foreign currency assets is easiest to see if we rewrite equations (28) and (29) as follows (see the Technical Appendix for details):

$$
\begin{gathered}
n_{t}^{d o m}=\frac{i_{t}^{h}-i_{t}^{f}-\varepsilon_{t}-\sigma_{E, t}^{m} \sigma_{T, t}^{m}-n_{t}^{k}\left(\left(\sigma_{E, t}\right)^{2}-\sigma_{E, t} \sigma_{Q, t}\right)+\left(\sigma_{E, t}\right)^{2}}{\left(\sigma_{E, t}\right)^{2}}, \\
n_{t}^{f}=\frac{i_{t}^{f}+\varepsilon_{t}-i_{t}^{h}+\sigma_{E, t}^{m} \sigma_{T, t}^{m}-n_{t}^{k} \sigma_{E, t} \sigma_{Q, t}}{\left(\sigma_{E, t}\right)^{2}} .
\end{gathered}
$$

Numerically, the terms multiplying $n_{t}^{k}$ in each equation are almost identical in our baseline calibration. This leaves two main differences between equations (31) and (32).

The first difference is the presence of exchange rate volatility $\left(\sigma_{E, t}\right)^{2}$ in the numerator of the domestic but not the foreign currency share, which tends to make the former much larger than the latter. In the limit, for an increase in exchange rate volatility not accompanied by an equal increase in domestic price volatility, the foreign currency share goes towards zero but the domestic currency share goes towards $\left(1-n_{t}^{k}\right)>0$. The reason for this difference is that, while all assets are equally subject to domestic price volatility $\left(\sigma_{P, t}\right)^{2}$ (this follows from (12)), only foreign currency bonds are subject to exchange rate volatility $\left(\sigma_{E, t}\right)^{2}$, and the exposure to that risk is reduced by holding a larger share of domestic currency assets. Holding domestic physical capital performs a similar function but to a lesser extent, given the positive correlation between the exchange rate and producer prices $\sigma_{E, t} \sigma_{Q, t}$. Furthermore, the foreign government does not provide partial insurance against this exchange rate volatility through lump-sum taxes/transfers to domestic agents.

This leads us to the second difference between equations (31) and (32), the sign with which the correlation between the exchange rate and taxes $\sigma_{E, t}^{m} \sigma_{T, t}^{m}=-n_{t}^{d o m} \sigma_{E, t}^{m} \sigma_{P, t}^{m}$ enters. This term derives from the assumption of asymmetric seigniorage redistribution in (21), which requires that taxes increase when prices fall in order to tax away valuation gains. The component $\sigma_{E, t}^{m} \sigma_{P, t}^{m}$ is positive due to standard monetary and fiscal transmission channels, and the component $n_{t}^{d o m}$ is positive under all feasible calibrations, partly by the argument in the previous paragraph and partly due to the need for households to hold cash, $n_{t}^{m}>0$. 
The correlation term $\sigma_{E, t}^{m} \sigma_{T, t}^{m}$ is therefore negative, which means that the payoff on foreign currency bonds is higher at times when taxes are low. This makes them less attractive for domestic investors than domestic currency bonds, where the opposite is true. This channel for imperfect asset substitutability is absent in models that ignore fiscal policy.

\subsection{Equilibrium Diffusions}

The Technical Appendix derives a set of equilibrium conditions that determine the four diffusions for money, consumer prices, producer prices and the exchange rate. There are three equilibrium conditions for each shock, with the fourth condition in each case supplied by an exogenous monetary or fiscal forcing term.

The first condition follows directly from the stochastic differentiation of the CPI price level equation (16) and relates the CPI diffusion to the underlying diffusions of domestic and foreign goods prices and of the nominal exchange rate:

$$
\sigma_{P, t}^{j}=\gamma \sigma_{Q, t}^{j}+(1-\gamma)\left(\sigma_{E, t}^{j}+\sigma_{Q^{*}, t}^{j}\right) \quad, \quad j=M, M^{*}, G, G^{*} .
$$

The second condition follows from the stochastic differentiation of the aggregate consumption optimality condition (27), the cash constraint (11), and the capital accumulation equation (15). We end up with the following simple results:

$$
\begin{gathered}
\sigma_{Q, t}^{j}=\sigma_{M, t}^{j} \quad, \quad j=M, M^{*}, G^{*}, \\
\sigma_{Q, t}^{G}=\sigma_{M, t}^{G}+\sigma_{G}^{G} .
\end{gathered}
$$

This states that domestic producer prices move one for one with nominal money balances in response to all shocks except the domestic fiscal shock, where they rise in addition in response to government spending. This is because such shocks reduce the supply of domestic output that is available for private consumption.

The third condition follows from the stochastic differentiation of the private sector asset stock combined with the flow equation for private sector assets. We obtain:

$$
\sigma_{M}^{M}=\frac{n_{t}^{f}}{n_{t}^{f i n}} \sigma_{E, t}^{M}+\frac{\left(n_{t}^{m}+n_{t}^{h}\right)}{n_{t}^{f i n}} \sigma_{P, t}^{M},
$$




$$
\begin{gathered}
\sigma_{M, t}^{M^{*}}=\frac{n_{t}^{f}}{n_{t}^{f i n}} \sigma_{E, t}^{M^{*}}+\frac{\left(n_{t}^{m}+n_{t}^{h}\right)}{n_{t}^{f i n}} \sigma_{P, t}^{M^{*}} \\
\sigma_{M, t}^{G}=\frac{n_{t}^{k}}{n_{t}^{f i n}} \sigma_{G}^{G}+\frac{n_{t}^{f}}{n_{t}^{f i n}} \sigma_{E, t}^{G} \\
\sigma_{M, t}^{G^{*}}=\frac{n_{t}^{f}}{n_{t}^{f i n}} \sigma_{E, t}^{G^{*}} .
\end{gathered}
$$

In equation (36) money is exogenous, while in equations (37)-(39) money is an endogenous variable that has to accommodate changes in exchange rates and prices in order to allow the government to support its desired bond stock $B_{t}$, or more intuitively to support the nominal interest rate implied by that bond stock. Equation (36) shows that exogenous domestic money supply shocks are related to price inflation in all three financial asset classes in proportion to their share in the overall asset portfolio. Equation (37) shows that an identical relationship holds for foreign money supply shocks. The reason is that, following an expansionary foreign money shock, domestic money supply is contracted to support fiscal policy as it taxes away the valuation gains on domestic currency assets resulting from exchange rate appreciation and lower prices. Without this fiscal compensation, as in equation (39), the domestic money supply response to foreign shocks is limited to the transmission of exchange rate shocks through the endogenously small portfolio share $n_{t}^{f}$. Domestic fiscal shocks, by (38), do of course require a powerful monetary accommodation to revalue nominal asset stocks.

A key feature of equations (33)-(39) is that in this model the volatility of prices and exchange rates is determined by the interplay of goods and asset market shares. The latter is completely absent in conventional models.

\subsection{Computation of Equilibrium}

The interesting part of our model's dynamics is fully captured by its instantaneous impulse responses, that is by its diffusions. Beyond that, dynamic paths are not informative because the underlying asset stocks evolve as nonstationary Itô processes. But because 
optimal portfolio shares, marginal propensities to consume out of wealth, and capital to wealth ratios are independent of asset stocks, an analysis of equilibria for a given set of state variables conveys all the necessary information. We therefore compute the model's equilibrium at a given point in time, for a given set of state variables $a_{t}^{c}, a_{t}^{c^{*}}, K_{t}, K_{t}^{*}, M_{t}, M_{t}^{*}, \tilde{f}_{t}$, and then examine its characteristics by conducting sensitivity analysis with respect to a number of key parameters. Each equilibrium is characterized by a large simultaneous equation system that is solved by way of a Newton algorithm.

\subsection{Government Bond Market Interventions}

Section 5 studies large discontinuous government open market operations that exchange bonds $B_{t}$ for money $M_{t}$. Because such events are rare, they are modeled as oneoff, unanticipated events. Because they are discontinuous, the financial asset stocks $a_{t}^{c}, a_{t}^{c^{*}}, M_{t}, M_{t}^{*}$ and $\tilde{f}_{t}$ also become discontinuous, leaving only $K_{t}$ and $K_{t}^{*}$ as predetermined variables. We therefore need five additional relationships to determine the equilibrium jumps in asset stocks. We denote pre-intervention asset stocks by a bar above the respective variable, and post-intervention stocks by a time subscript $t$. We note that all net asset sales have to be transacted at the new rather than the old prices. We will restrict attention to unsterilized operations, that is operations which leave government foreign exchange reserves unchanged. Therefore we have

$$
\begin{gathered}
F_{t}^{g}=\bar{F}^{g}, \\
H_{t}^{g^{*}}=\bar{H}^{g^{*}} .
\end{gathered}
$$

Household behavior is described simply by the requirement that purchases and sales of financial assets have to be transacted at the new exchange rate:

$$
\begin{gathered}
E_{t}\left(F_{t}^{c}-\bar{F}^{c}\right)=-\left[\left(H_{t}^{c}-\bar{H}^{c}\right)+\left(M_{t}-\bar{M}\right)\right], \\
E_{t}^{*}\left(H_{t}^{c^{*}}-\bar{H}^{c^{*}}\right)=-\left[\left(F_{t}^{c^{*}}-\bar{F}^{c^{*}}\right)+\left(M_{t}^{*}-\bar{M}^{*}\right)\right] .
\end{gathered}
$$


Similar conditions have to hold for government purchases and sales of financial assets. The condition for Home is

$$
0=\left(H_{t}^{c}-\bar{H}^{c}\right)+\left(H_{t}^{c^{*}}-\bar{H}^{c^{*}}\right)+\left(H_{t}^{g^{*}}-\bar{H}^{g^{*}}\right)+\left(M_{t}-\bar{M}\right) .
$$

By Walras' Law we only need this one condition for Home, because the equivalent condition for Foreign is implied by (44) in combination with (42) and (43).

To simulate government bond market interventions we first simulate the baseline model without these five equations to obtain the pre-intervention asset stocks. We then add (40)(44) and re-simulate after resetting the exogenous policy variable, specifically the desired government debt to GDP ratio $b g d p_{t}=B_{t} /\left(P_{t} * g d p_{t}\right)$, to a post-intervention value.

\section{The Baseline Economy}

\subsection{Calibration}

We adopt a symmetric baseline calibration. For consumer preferences we assume significant home bias, with $80 \%$ of domestic demand falling on domestic goods, or $\gamma=\gamma^{*}=$ 0.8. In production we assume that capital stocks in each economy equal $25, K_{t}=K_{t}^{*}=25$, and that capital has a constant real return of four percent, $r=r^{*}=0.04$. This implies a real domestic output of one in each economy. We choose personal discount rates $\beta$ and $\beta^{*}$ to normalize consumption to one, $c_{t}=c_{t}^{*}=1,{ }^{20}$ and we choose money stocks $M_{t}$ and $M_{t}^{*}$ to normalize consumer prices to one, $P_{t}=P_{t}^{*}=1$. Together with the rest of the calibration this also implies producer prices and real exchange rates approximately equal to one. Average inflation rates are pinned down by the choice of nominal money growth rates at 3 percent per annum, $\mu_{t}=\mu_{t}^{*}=0.03$

A critical part of calibrating the model concerns financial assets to GDP ratios. For symmetry we assume that the net foreign asset position between the two countries is

\footnotetext{
20 The resulting endogenous values for personal discount rates $\beta \simeq \beta^{*} \simeq 0.0395$ are of course very close to those for real returns to capital.
} 
zero. The government's foreign exchange reserves are assumed to cover 5 percent of its money stock, a small value that is consistent with central bank practice in most advanced industrialized countries. The government debt to GDP ratios are fixed at 40 percent, by allowing nominal interest rates to take values consistent with portfolio equilibrium at those debt ratios. To set the money stock to GDP ratio we choose M1 as representing the model's monetary aggregate $M_{t}$. This is a compromise between choosing the monetary base, which would be the appropriate choice to represent money in the government's budget constraint, and choosing M2, which is more appropriate to represent the quantity of money relevant to households' spending decisions, and therefore to the calibration of velocity $\alpha$. M1 is in fact much closer in size to the monetary base than to M2, which means most importantly that interest rates will have a limited direct effect on consumption decisions via the cash constraint effect in optimality condition (27) because the implied velocity is large.

We use monthly U.S. data from January 1984 through December 2007 to calibrate monetary magnitudes, which are again assumed to be symmetric across countries. This implies a money stock to GDP ratio of 12 percent, and therefore requires $\alpha \simeq \alpha^{*} \simeq 8.333$. The same data can also be used to estimate the volatilities of exogenous shocks. The standard deviation of U.S. M1 growth over the sample period equals 0.05. For our baseline we assume that half of this reflects endogenous money supply responses to shocks, with the other half reflecting exogenous money supply shocks. This requires $\sigma_{M}^{M}=\sigma_{M^{*}}^{M^{*}}=0.025$ and $\sigma_{G}^{G}=\sigma_{G^{*}}^{G^{*}}=0.000736$. We will conduct sensitivity analysis with respect to these volatilities.

\subsection{Baseline Portfolio Equilibrium}

The baseline equilibrium outcome for financial asset portfolios is striking. Domestic households hold domestic currency denominated government bonds equal to 39.4 percent of GDP, with the remaining 0.6 percent held by the foreign government. Because the standard deviation of the exchange rate $\sigma_{E_{t}}=0.086$ is much higher than that of domestic prices $\sigma_{Q_{t}}=0.05$, households dislike foreign currency exposure and make domestic currency 
loans to foreign households equal to only 0.75 percent of GDP, with foreign households, by symmetry, behaving identically. ${ }^{21}$ In other words, households go long in domestic currency but take a small short position in foreign currency. This outcome is very different from the results on optimal cross-border equity holdings, which typically find that it is optimal for households to diversify by taking a large long position in foreign equity. But on the other hand, it is consistent with the empirical findings of Lane and Shambaugh (2009).

The aspect of these results that we wish to stress is the small size of the foreign currency exposure, and its negative dependence of exchange rate volatility, rather than its sign. If we allowed for additional types of shocks the sign of the exposure might well change, but the portfolio equations show that, as long as there is sufficient nominal exchange rate volatility, its size will remain small.

\section{Comparing Alternative Economies}

In this section we consider economies for which all aspects of the calibration are identical to the baseline except in one dimension. We stress that this is different from analyzing the response of the economy to shocks by way of impulse responses.

In the graphs used to illustrate our results, each subplot shows the value of the varied parameter or variable along the horizontal axis, and the value of a number of key endogenous variables along the vertical axis. Interest rates and inflation rates are shown in percentage points, prices and allocations are shown in percent deviations from the baseline economy, and asset stocks are shown as stock to GDP ratios.

\footnotetext{
21 Households' foreign lending and borrowing exposures are exactly equal only because we have assumed zero net foreign assets and symmetric behavior for governments. Many alternative configurations are possible but are omitted here to conserve space.
} 


\subsection{Standard Deviation of Monetary Shocks}

Figure 2 varies $\sigma_{M}^{M}$ around its baseline value of $2.5 * 10^{-2}$, specifically between $0.1 * 10^{-2}$ and $10.0 * 10^{-2}$. Values along the horizontal axis are shown as $\sigma_{M}^{M} * 10^{2}$.

Price volatility in Home increases sharply as monetary volatility increases. A Home monetary expansion, by depreciating the exchange rate and thereby reducing Foreign's consumer price index, leads to valuation gains on Foreign households' domestic currency assets, and the resulting Foreign tax increase leads to a Foreign monetary contraction that is roughly equal in size to Home's monetary expansion. As a result exchange rate volatility increases more sharply than price volatility.

Higher domestic price volatility increases the demand for local currency denominated assets relative to domestic capital. But because the capital stock is predetermined and the government fixes its debt stock at 40 percent of GDP, there is no significant stock substitution possibility. Instead the greater attractiveness of domestic currency assets is reflected in the fact that the government is able to pay a lower nominal and real return as volatility increases. Over the range of monetary volatilities considered here, the Home nominal interest rate falls from 6.8 percent to 5.8 percent, and the real interest rate $\tilde{r}_{t}^{h}$, shown under "Real Return Drifts", falls from 3.8 percent to 2.9 percent.

Unlike for capital, there is a possibility of stock substitution between bonds of different currencies, and it is here that we observe the critical role of asymmetric seigniorage redistribution. Specifically, as monetary volatility increases the resulting increase in exchange rate volatility drives the optimal amount of private domestic currency lending and foreign currency borrowing down to only 0.1 percent of GDP. It also requires an increasing mean return on foreign currency assets, and therefore a significant increase in the deviation from real interest parity $\tilde{r}_{t}^{f}=\tilde{r}_{t}^{h}$.

As for nominal returns in Foreign, we observe that a policy of compensating Foreign asset holders for Home monetary volatility keeps nominal interest rates closely aligned as monetary volatility increases. In our specific calibration Foreign interest rates in fact fall 
slightly more than Home rates. Ceteris paribus this stimulates the relative demand for Foreign output, so that Foreign prices are relatively higher as volatility increases. Higher prices however imply lower real wealth, so that Foreign consumption is in fact lower than Home consumption at higher volatilities, despite its slightly lower interest rate. More generally, when comparing the direct effect of interest rates on consumption to the wealth effect induced by the resulting price changes, the latter is always dominant. Because lower interest rates are associated with higher volatility, this means that more volatility is associated with lower output and consumption.

\subsection{Standard Deviation of Fiscal Shocks}

Figure 3 varies $\sigma_{G}^{G}$ around its baseline value of $\sigma_{G}^{G}=0.736 * 10^{-3}$, specifically between $0.010 * 10^{-3}$ and $2.500 * 10^{-3}$. Values along the horizontal axis are shown as $\sigma_{G}^{G} * 10^{3}$.

Price volatility in Home increases sharply as fiscal volatility increases. But the effect on exchange rate volatility is more muted because Foreign fiscal policy does not tax away Home induced valuation gains under this shock. Higher domestic price volatility, both absolutely and relative to exchange rate volatility, has two effects. First it increases the demand for local currency denominated assets and allows the Home government to pay a lower nominal and real interest rate on its debt. Because of low volatility spillovers the Foreign interest rate is virtually unaffected. Second, higher domestic price volatility strongly increases the incentive to increase private borrowing in foreign currency in order to fund private lending in domestic currency.

Figure 3 addresses the potential criticism that our baseline assumption of a 50 percent share of monetary volatility that is due to fiscal factors may be arbitrary, by varying that share between close to zero and close to 100 percent. The main conclusion is that portfolios remain determinate and well-behaved even as fiscal volatility becomes very small but not zero. The previously discussed results of Click (1998) strongly suggest that an assumption of zero fiscal volatility would not be appropriate. 


\subsection{Government Debt to GDP Ratios}

In our baseline calibration the government debt to GDP ratio is held constant at 40 percent. Figure 4 varies that ratio between 0 percent and 80 percent. The key implication of larger nominal government obligations is that they constitute a larger base for the stochastic inflation tax, which implies that any given shock causes less volatility of domestic prices. Because less volatility decreases the amount of domestic currency bonds that households are willing to hold, the government is then required to pay a higher interest rate to be able to place the additional debt. Figure 4 shows that this effect on volatilities and interest rates gets smaller as government debt increases, which reflects decreasing returns of increases in the inflation tax base. At very low levels of outstanding government debt the real interest rate has to rise by more than 20 basis points for a 1 percentage point increase in the government debt to GDP ratio, while at more elevated debt levels that elasticity drops to around 1 basis point. Interestingly, over the relevant range these values are of the same order of magnitude as the empirical results of Engen and Hubbard (2004), Gale and Orszag (2004) and Laubach (2003), who estimate that elasticity to be between 1 and 6 basis points.

\section{Open Market Operations in Government Debt}

Figure 5 assumes that the economy starts from a baseline government debt to GDP ratio of 40 percent, and that thereafter, in order to change that ratio, the government conducts unsterilized open market operations in accordance with equations (40)-(44).

A large unsterilized open market sale causes a large contraction of the nominal money stock. Given the cash constraint, the proportionality of consumption to the state variable wealth, and the small direct effect of interest rate changes on consumption, the contraction in the money stock must lead to a nearly proportional fall in the price level and the exchange rate, with real money balances remaining nearly constant. The lower price level however increases the real value of Home non-monetary wealth and thereby supports higher consumption. 
A higher real value of outstanding government liabilities increases the base of the inflation tax in Home and therefore reduces volatility of Home prices, while the volatility of Foreign prices increases. The result of these opposing trends is that exchange rate volatility is slightly U-shaped around the 40 percent of GDP baseline. This implies that private sector gross lending positions decrease with sufficiently large open market sales or purchases, but the magnitude of this effect is small. More importantly, to allow Home to place additional government debt with households in the face of lower domestic price volatility, it must raise the nominal interest rate. Given higher volatility in Foreign, the government there can lower interest rates.

We now turn to net foreign asset valuation effects. In our baseline the public sector is assumed to take a long position in foreign currency, while being short domestic currency, vis-à-vis foreigners. The private sector on the other hand optimally chooses the opposite exposure. When prices and the exchange rate fall, the public sector therefore loses as the domestic currency value of its assets falls, while the private sector gains as the domestic currency value of its liabilities falls. The overall valuation gain of Home depends on the economy's aggregate foreign currency exposure. In our example the private sector's exposures are barely larger than those of the public sector. We therefore observe a very small positive valuation effect.

It can be shown that valuation gains can become larger under assumptions that lower exchange rate volatility relative to domestic price volatility, because in that case the private sector's negative foreign currency exposures become larger. Due to these valuation effects the consumption gains also increase. Conversely, valuation gains become negative if the public sector's positive foreign currency exposure increases. To quantify this we assume a different baseline where both governments start with liabilities equal to 60 percent of GDP and foreign exchange reserves equal to 20 percent of GDP. Private sector positions are not materially different under this case. For an open market sale equal to $10 \%$ of GDP, this turns 
Figure 5's valuation gains of $0.03 \%$ of GDP into valuation losses of $2.5 \%$ of GDP. ${ }^{22}$

The foregoing suggests that under volatile exchange rates a large aggregate negative net foreign asset position driven by government borrowing in domestic currency is hard to rationalize as a result of private sector portfolio choice, and must therefore have a large inter-governmental component. This would impose an important constraint on the ability of a government to finance its debt abroad. To show this we attempt to compute equilibria, starting at the baseline, where the Home economy's net foreign assets to GDP ratio deteriorates accompanied by an equal sized increase in its government debt to GDP ratio. Given the aversion of Home and Foreign private sectors to large foreign currency exposures, such equilibria can only be computed for fairly small changes in net foreign asset levels (less than 5\% of GDP) unless there is a concomitant increase in the foreign exchange reserves of Foreign's government.

This result implies that if a government desires to significantly increase its foreign indebtedness in its own currency, the willingness of foreign governments to hold the extra debt is critical because the ability to attract private financing may be limited. The only alternative is for Home's government to issue the additional debt in Foreign rather than Home currency, because such issues are easy to place with Foreign households. Going beyond this model, the problem might also be mitigated if Home's government debt had an additional international liquidity role..$^{23}$

\section{Conclusions}

This paper has developed a theory of international currency portfolios that holds in general equilibrium, and that is therefore not subject to the criticisms directed at the portfolio balance literature of the 1980s. Like that literature, the theory stresses the critical roles of government debt and of government policies. The main ingredients needed to obtain

\footnotetext{
22 The results mentioned in this paragraph are available from the author on request.

23 If Home government debt entered the utility function of Foreign households, this would generate an additional portfolio demand that is independent of risk-financial return considerations.
} 
determinate portfolio shares in general equilibrium are more plausible assumptions about fiscal policy than have so far been considered by the literature. The key implication for prices is that the relationship between the rates of return of bonds denominated in different currencies is not correctly described by the uncovered interest parity arbitrage relationship but instead also depends on outstanding bond stocks. The key implication for quantities is that it becomes possible to go beyond the study of international portfolios consisting only of private assets, to the study of the currency composition of international nominal bond portfolios that contain a large government debt component.

This yields several new insights. First, the optimal private sector foreign currency position is small and possibly negative, with its size decreasing in exchange rate volatility. Large negative aggregate net foreign asset positions driven by government borrowing in domestic currency can only be rationalized by assuming large domestic currency lending by foreign governments. Second, the optimal portfolio share of domestic currency denominated assets is large, and there is a monotonically increasing relationship between that share and domestic nominal interest rates. This relationship is steep at low levels of government debt, and almost flat at high levels of government debt. Third, for a baseline calibration with zero aggregate net foreign assets, unsterilized open market sales of domestic government debt appreciate the currency, increase output and consumption, and lead to valuation gains when the country as a whole has a negative exposure to foreign currency. Fourth, a fiscal theory of exchange rate determination is compatible with general equilibrium in a two-country world in which both governments' primary surpluses are exogenous.

The focus of this paper is distinct from the growing literature on international portfolio diversification in DSGE models. That literature focuses on diversification among alternative private claims whose imperfect substitutability is given, and where the main theoretical challenge is the computation rather than the existence of a portfolio equilibrium. The older portfolio balance literature was largely abandoned precisely because for government bonds imperfect substitutability could not be derived from first principles. This paper attempts to 
do so, and thereby to reconnect to that older literature. This is in fact an important task, because the currently existing global imbalances problems are not just, or even mainly, a question of real private claims. Nominal public claims are an extremely important part of the problem.

But of course private claims are also important, and this paper has abstracted from their equity component by assuming complete home bias in equity. In future work this model will therefore be extended to allow for internationally traded equity. That model will then connect to both the older and the more recent literatures on international portfolio choice.

\section{References}

Aizenman, J. (1989), "Country Risk, Incomplete Information and Taxes on International Borrowing”, Economic Journal, 99, 147-161.

Arellano, C. (2008), "Default Risk and Income Fluctuations in Emerging Economies", American Economic Review, 98(3), 690-712.

Backus, D.K. and Kehoe, P.J. (1989), "On the Denomination of Government Debt - A Critique of the Portfolio Balance Approach", Journal of Monetary Economics, 23, 359-376.

Bakshi, G.S. and Chen, Z. (1997), "Equilibrium Valuation of Foreign Exchange Claims", Journal of Finance, 52, 799-826.

Bergin, P. (2000), "Fiscal Solvency and Price Level Determination in a Monetary Union", Journal of Monetary Economics, 45, 37-53.

Blanchard, O., Giavazzi, F. and Sa, F. (2005), “The U.S. Current Account and the Dollar", NBER Working Paper No. 11137.

Branson, W.H. and Henderson, D.W. (1985), "The Specification and Influence of Asset Markets", Ch. 15 in: Handbook of International Economics, vol. 2.

Burger, J.D. and Warnock, F.E. (2003), "Diversification, Original Sin, and International Bond Portfolios", Board of Governors of the Federal Reserve System, International Finance Discussion Paper No. 755.

Burnside, C., Eichenbaum, M., Kleshchelski, I. and Rebelo, S. (2007), "The Returns to Currency Speculation in Emerging Markets", NBER Working Paper No. 12916.

Canzoneri, M.B., Cumby, R.E. and Diba, B.T. (2004),"Is the Price Level Determined by the Needs of Fiscal Solvency?”, American Economic Review, 91(5), 1221-1238. 
Chow, G.C. (1979), "Optimum Control of Stochastic Differential Equation Systems", Journal of Economic Dynamics and Control, 1, 143-175.

Click, R.W. (1998), "Seigniorage in a Cross-Section of Countries", Journal of Money, Credit and Banking, 30(2), 154-171.

Coeurdacier, N., Kollman, R. and Martin, P. (2007), "International Portfolios with Supply, Demand and Portfolio Shocks", NBER Working Paper No. 13424.

Cox, J.C., Ingersoll, J.E. and Ross, S.A. (1985), "An Intertemporal General Equilibrium Model of Asset Prices", Econometrica, 53(2), 363-384.

Daniel, B. (2001), "A Fiscal Theory of Currency Crises”, International Economic Review, 42, 969-988.

Devereux, M.B. and Engel, C. (1998), "Fixed versus Floating Exchange Rates: How Price Setting Affects the Optimal Choice of Exchange Rate Regime", NBER Working Paper No. 6867.

Devereux, M.B. and Sutherland, A. (2006), "Monetary Policy Rules and International Portfolio Choice", Working Paper, University of British Columbia and University of St. Andrews.

Dominguez, K.M. and Frankel, J.A. (1993), "Does Foreign-Exchange Intervention Matter? The Portfolio Effect", American Economic Review, 83(5), 1356-1369.

Duffie, D. (1996), Dynamic Asset Pricing Theory, 2nd edition, Princeton University Press, Princeton, NJ.

Dupor, B. (2000), "Exchange Rates and the Fiscal Theory of the Price Level", Journal of Monetary Economics, 45, 613-630.

Eaton, J. and Gersovitz, M. (1981), "Debt with Potential Repudiation: Theoretical and Empirical Analysis", Review of Economic Studies, 48, 289-309.

Engel, C. (1992), "On the Foreign Exchange Risk Premium in a General Equilibrium Model”, Journal of International Economics, 32, 305-319.

Engel, C. (1999), “On the Foreign Exchange Risk Premium in Sticky-Price General Equilibrium Models”, International Tax and Public Finance, 6(4), 491-505.

Engel, C. and Matsumoto, A. (2009), “The International Diversification Puzzle When Goods Prices Are Sticky: It's Really about Exchange-Rate Hedging, Not Equity Portfolios", American Economic Journal: Macroeconomics, 1(2), 155-88.

Engen, E.M. and Hubbard, R.G. (2004), "Federal Government Debt and Interest Rates", NBER Macroeconomics Annual, 19, 83-138.

Feenstra, R.C. (1986), "Functional Equivalence between Liquidity Costs and the Utility of Money", Journal of Monetary Economics, 17, 271-291. 
Fleming, W.H. and Rishel, R.W. (1975), Deterministic and Stochastic Optimal Control, Springer Verlag, New York, NY.

Gale, W. and Orszag, P. (2004), "Budget Deficits, National Saving, and Interest Rates," Brookings Papers on Economic Activity, 2, 101-187.

Grinols, E.L. and Turnovsky, S.J. (1994), "Exchange rate determination and asset prices in a stochastic small open economy", Journal of International Economics, 36, 75-97.

Henderson, D. and Rogoff, K. (1982), "Negative Net Foreign Asset Positions and Stability in a World Portfolio Balance Model", Journal of International Economics, 13, 85-104.

Karatzas, I. and Shreve, S.E. (1991), Brownian Motion and Stochastic Calculus, 2nd edition, Springer Verlag, New York, NY.

Kehoe, P.J. and Perri, F. (2002), "International Business Cycles with Endogenous Incomplete Markets", Econometrica, 70(3), 907-928.

Kletzer, K.M. and Wright, B.D. (2000), "Sovereign Debt as Intertemporal Barter", American Economic Review, 90(3), 621-639.

Kouri, P. (1983), "Balance of Payments and the Foreign Exchange Market: A Dynamic Partial Equilibrium Model", in: Bhandari, J. and Putnam, B., eds., Economic Interdependence and Flexible Exchange Rates, MIT Press: Cambridge, Mass., 116-156.

Laubach, T. (2003), "New Evidence on the Interest Rate Effects of Budget Deficits and Debt", Finance and Economics Discussion Series, 2003-12, Board of Governors of the Federal Reserve System.

Leeper, E. (1991), "Equilibrium under Active and Passive Monetary and Fiscal Policies", Journal of Monetary Economics, 27(2), 129-147.

Lewis, K.K. (1995), "Puzzles in International Financial Markets", chapter 37 in: Grossman, G. and Rogoff, K., eds., Handbook of International Economics, Vol. III, Elsevier.

Lucas, Robert E. jr. (1982), "Interest Rates and Currency Prices in a Two-Country World", Journal of Monetary Economics, 10, 335-359.

Lucas, Robert E. jr. (1990), "Liquidity and Interest Rates", Journal of Economic Theory, 50, 237-264.

Lustig, H. and Verdelhan, A. (2007), "The Cross Section of Foreign Currency Risk Premia and Consumption Growth Risk", American Economic Review, 97(1), 89-117.

Malliaris, A.G. and Brock, W.A. (1982), Stochastic Methods in Economics and Finance, 1st edition, Advanced Textbooks in Economics, Volume 17, Elsevier, Amsterdam.

Merton, R.C. (1969), "Lifetime Portfolio Selection under Uncertainty: The ContinuousTime Case", The Review of Economics and Statistics, 51, 239-246. 
Merton, R.C. (1971), "Optimum Consumption and Portfolio Rules in a Continuous-Time Model”, Journal of Economic Theory, 3, 373-413.

Obstfeld, M. (1982), “The Capitalization of Income Streams and the Effects of Open-Market Policy under Fixed Exchange Rates", Journal of Monetary Economics, 9, 87-98.

Obstfeld, M. and Rogoff, K. (1996), Foundations of International Macroeconomics, 1st edition, MIT Press, Cambridge, MA.

Obstfeld, M. and Rogoff, K. (1998), "Risk and Exchange Rates", NBER Working Paper No. 6694.

Obstfeld, M. and Rogoff, K. (2000), "New Directions for Stochastic Open Economy Models", Journal of International Economics, 50, 117-153.

Sargent, T.J. and Smith, B.D. (1988), "Irrelevance of Open Market Operations in Some Economies with Government Currency Being Dominated in Rate of Return", American Economic Review, 77(1), 78-92.

Sarno, L. and Taylor, M.P. (2001), "Official Intervention in the Foreign Exchange Market: Is It Effective and, If So, How Does It Work?”, Journal of Economic Literature, 39, 839-868.

Sims, C. (1997), "Fiscal Foundations of Price Stability in Open Economies", Working Paper, Yale University.

Stulz, R.M. (1984), "Currency Preferences, Purchasing Power Risks, and the Determination of Exchange Rates in an Optimizing Model", Journal of Money, Credit and Banking, 16(3), 302-316.

Stulz, R.M. (1987), “An Equilibrium Model of Exchange Rate Determination and Asset Pricing with Nontraded Goods and Imperfect Information", Journal of Political Economy, 95(5), 1024-1040.

Tille, C. and van Wincoop, E. (2008), "International Capital Flows”,.Working Paper, Geneva Graduate Institute and University of Virginia.

United States Treasury (2008), "Major Foreign Holders of Treasury Securities", available at http://www.ustreas.gov/tic/mfh.txt.

Uribe, M. and Yue, V.Z. (2006), "Country Spreads and Emerging Countries: Who Drives Whom?", Journal of International Economics, 69(1), 6-36.

Zapatero, F. (1995), "Equilibrium Asset Prices and Exchange Rates", Journal of Economic Dynamics and Control, 19, 787-811. 


$\begin{array}{crrr} & \text { World } & \text { United States } & \text { Euro Area } \\ \text { Domestic Debt Securities } & 59,723 & 25,800 & 13,129 \\ \text { Government } & 28,324 & 7,323 & 6,500 \\ \text { Financial } & 24,992 & 15,512 & 4,799 \\ \text { Corporate } & 6,407 & 2,965 & 1,829 \\ \text { International Debt Securities } & 23,369 & 6,062 & 10,608 \\ \text { Government } & 1,896 & 4 & 1,233 \\ \text { Financial } & 19,022 & 5,177 & 8,639 \\ \text { Corporate } & 2,451 & 881 & 735\end{array}$

Table 1: World Debt Securities Markets

Amounts Outstanding September 2008, U.S. \$ Bn

(Source: Bank for International Settlements, Gian-Maria Milesi-Ferretti)

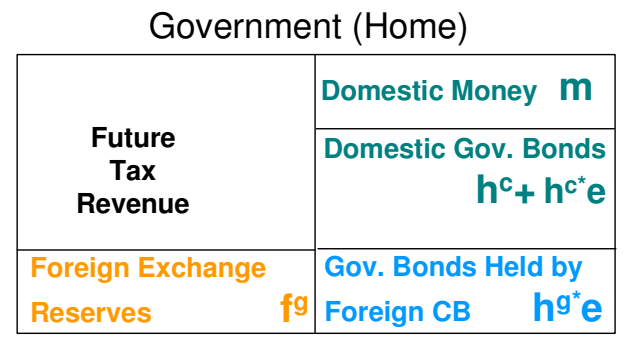

Households (Home)

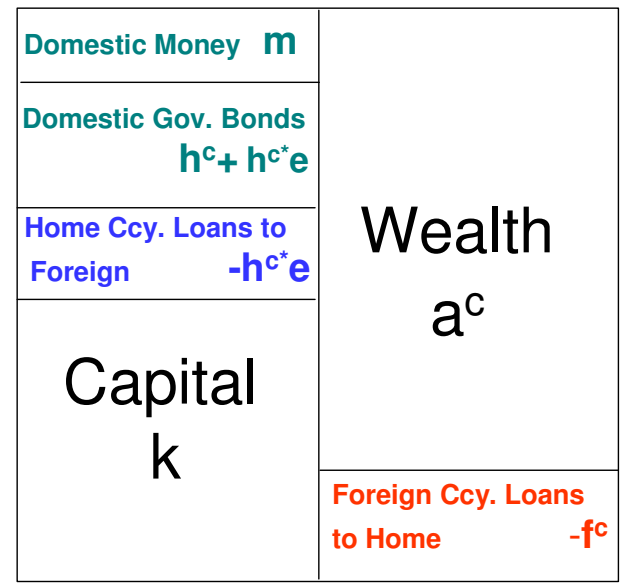

Government (Foreign)

\begin{tabular}{|c|r|}
\hline \multirow{2}{*}{$\begin{array}{c}\text { Future } \\
\text { Tax } \\
\text { Revenue }\end{array}$} & \begin{tabular}{r} 
Domestic Money $m$ \\
\cline { 2 - 2 }
\end{tabular} \\
\cline { 2 - 2 } $\begin{array}{l}\text { Foreign Exchange } \\
\text { Reserves }\end{array}$ & $\mathrm{fc}^{*}$ \\
\hline
\end{tabular}

Households (Foreign)

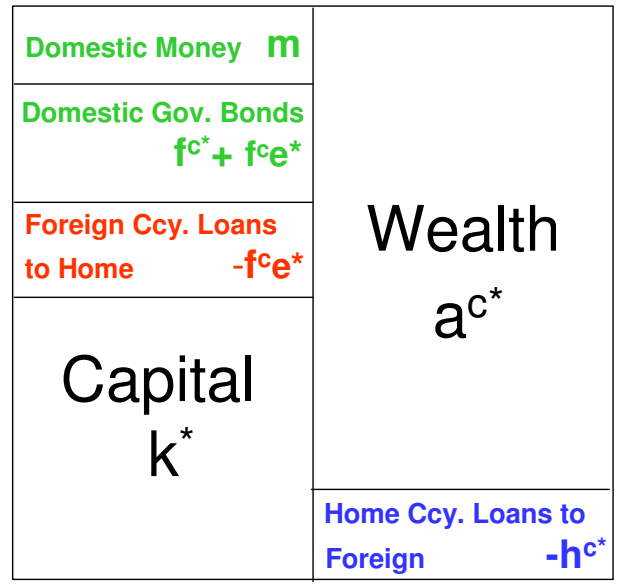

Figure 1: Household and Government Balance Sheets 

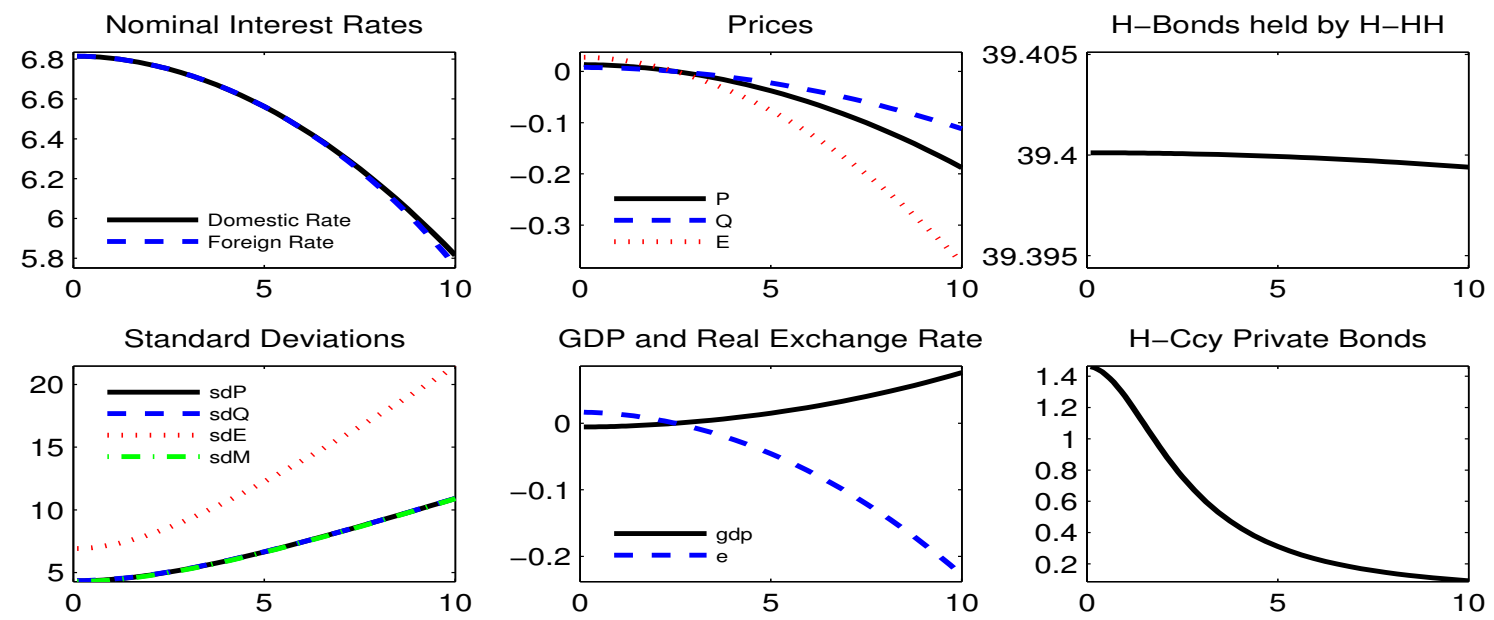

GDP and Real Exchange Rate
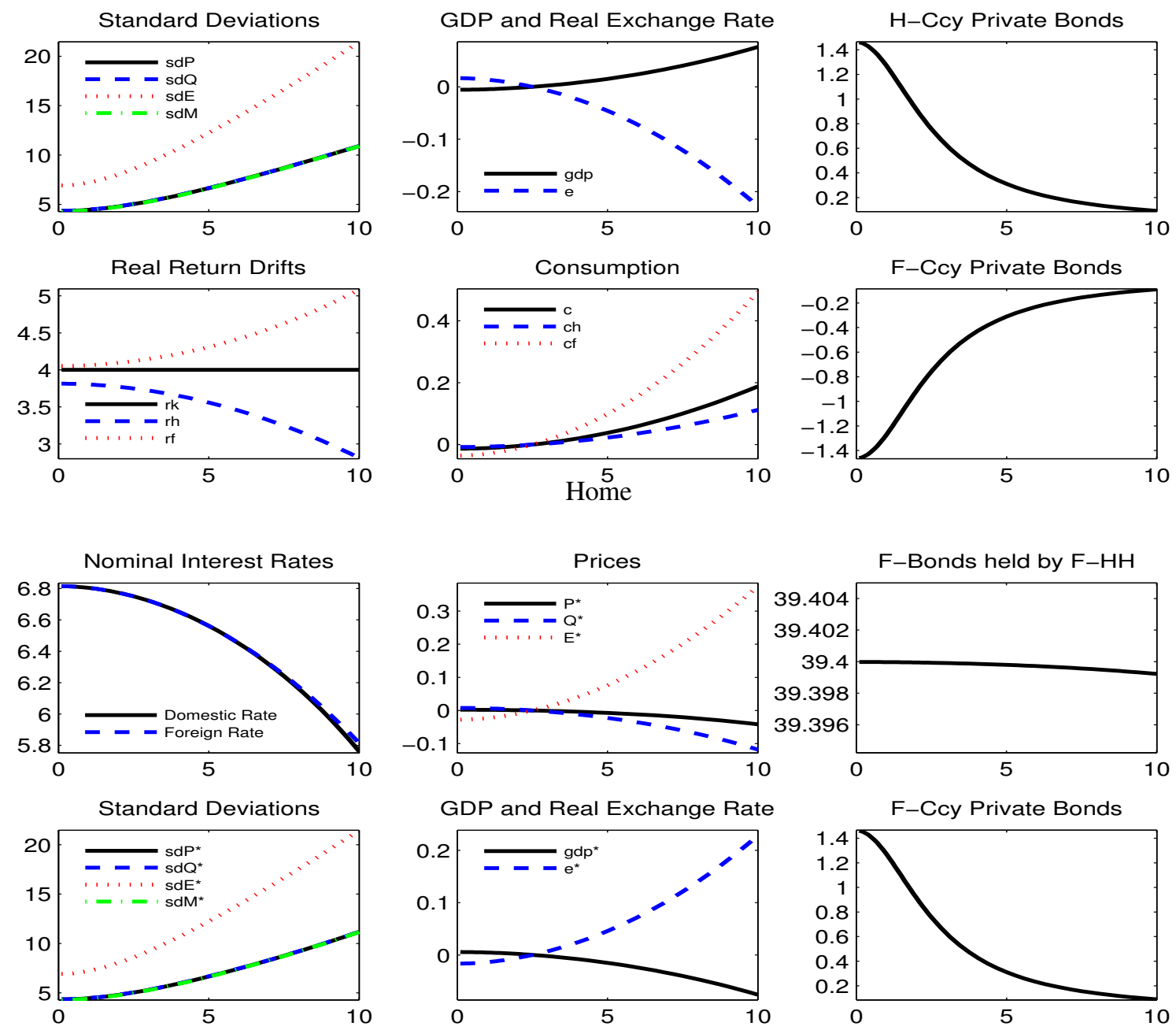

GDP and Real Exchange Rate
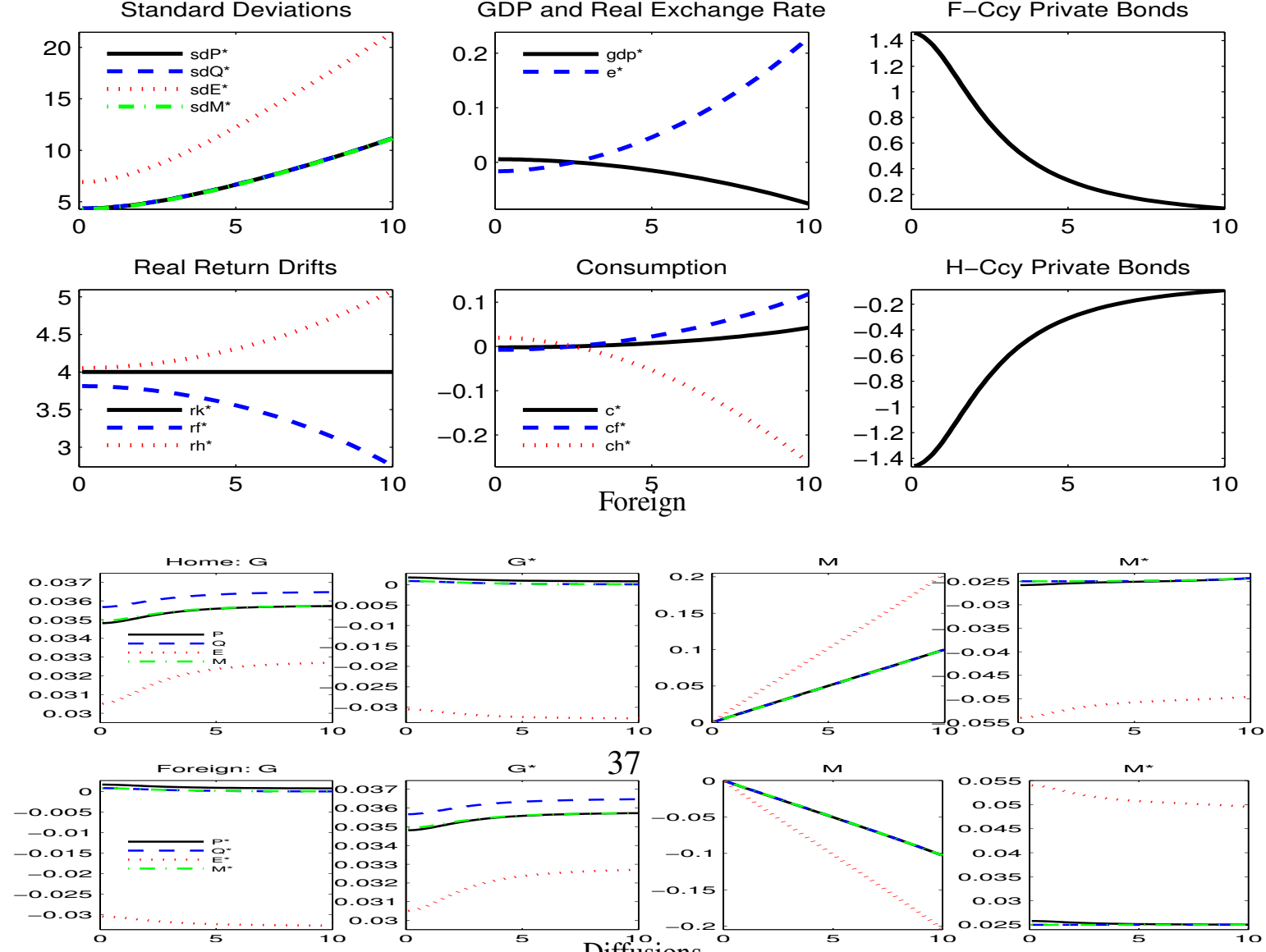

\section{Diffusions}

Figure 2: Effects of Money Supply Volatility 
Nominal Interest Rates
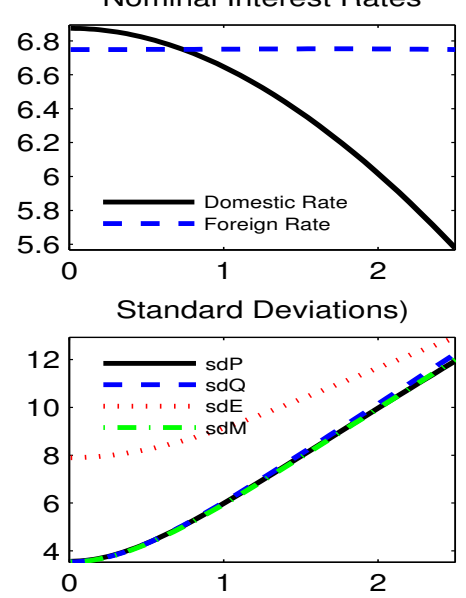

Real Return Drifts

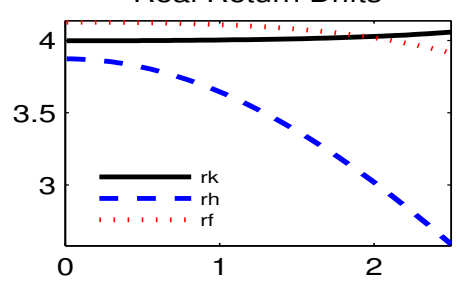

Nominal Interest Rates

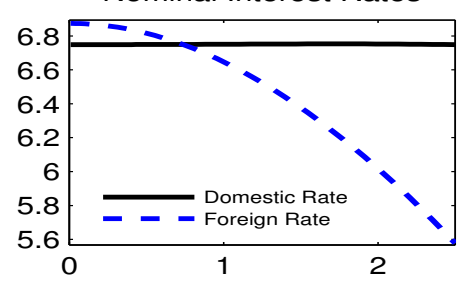

Standard Deviations

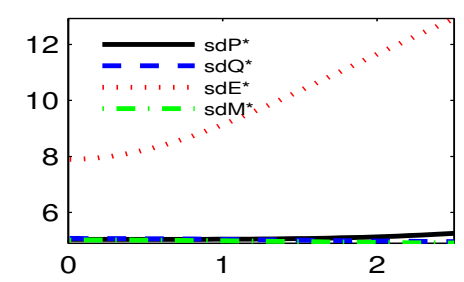

Real Return Drifts

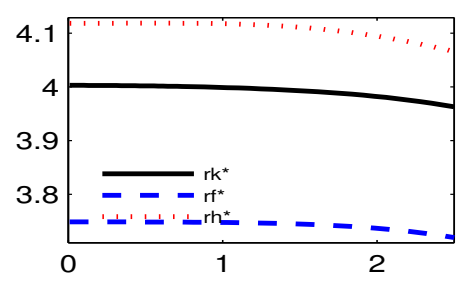

Prices

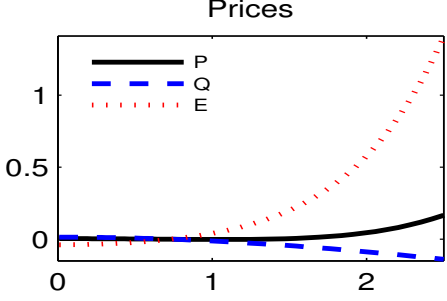

GDP and Real Exchange Rate

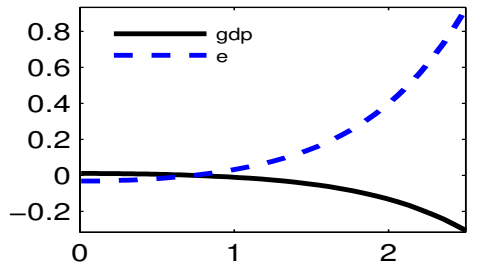

Consumption

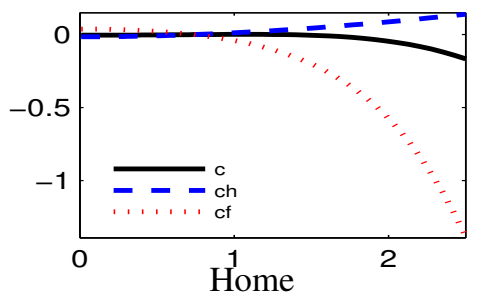

Prices

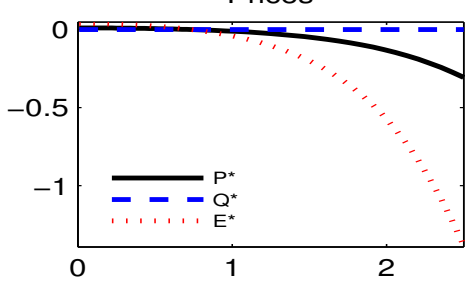

GDP and Real Exchange Rate

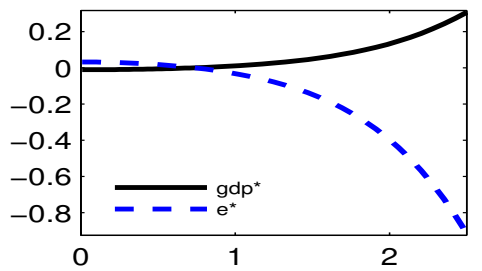

Consumption

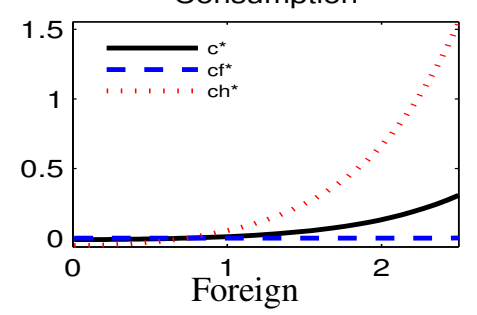

$\mathrm{H}-$ Bonds held by $\mathrm{H}-\mathrm{HH}$

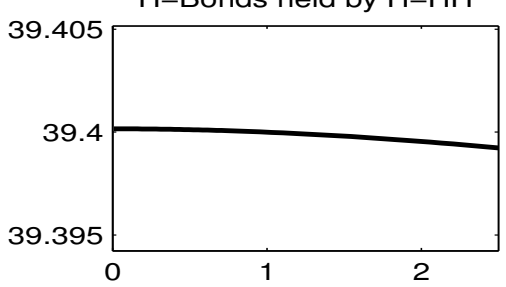

H-Ccy Private Bonds
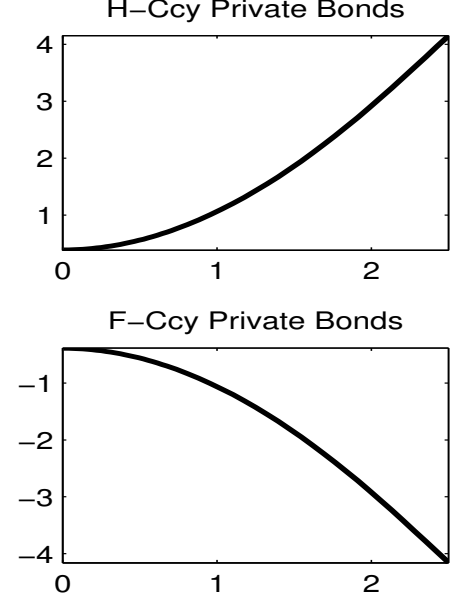

F-Bonds held by $\mathrm{F}-\mathrm{HH}$

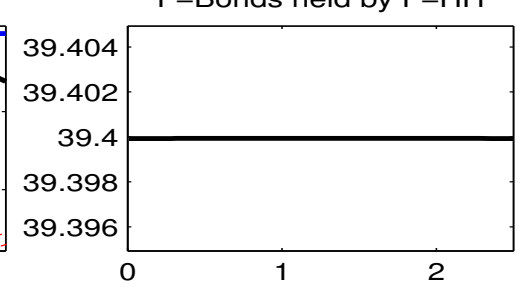

F-Ccy Private Bonds
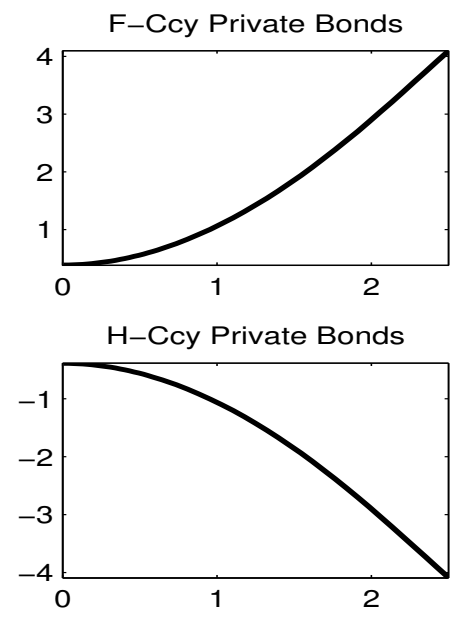
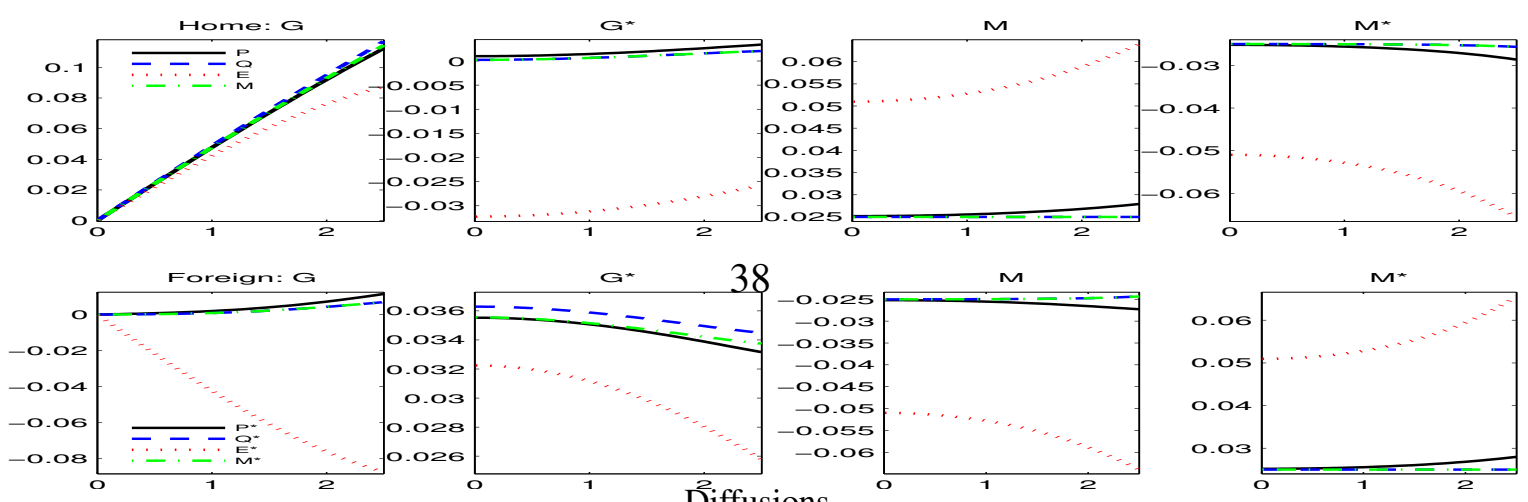

Diffusions

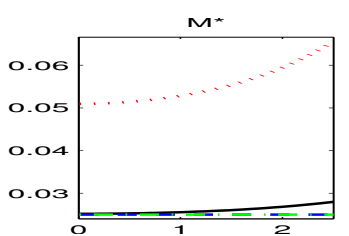

Figure 3: Effects of Government Spending Volatility 
Nominal Interest Rates

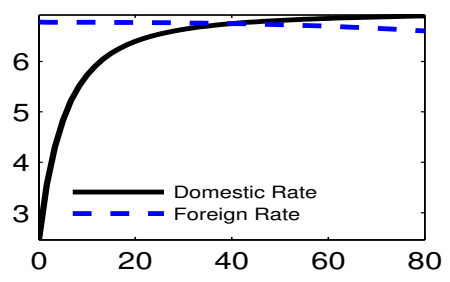

Standard Deviations

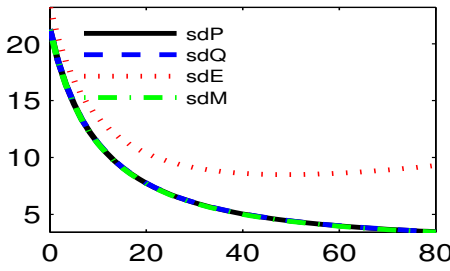

Real Return Drifts
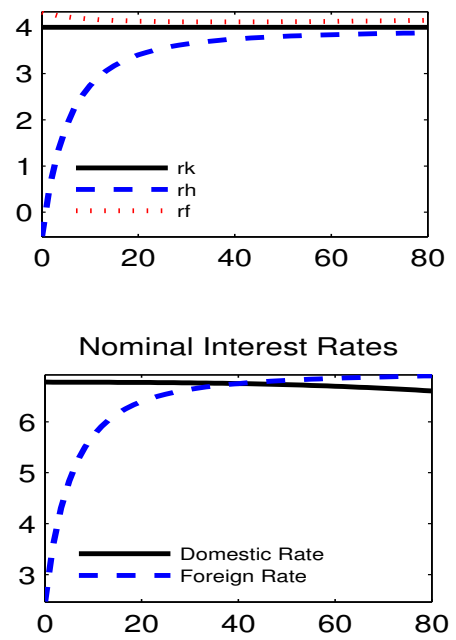

Standard Deviations

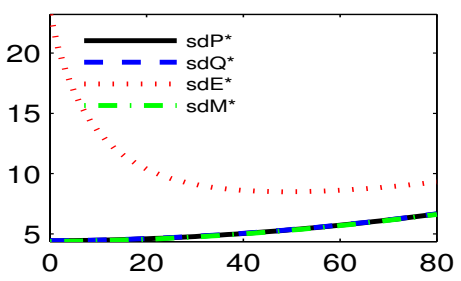

Real Return Drifts

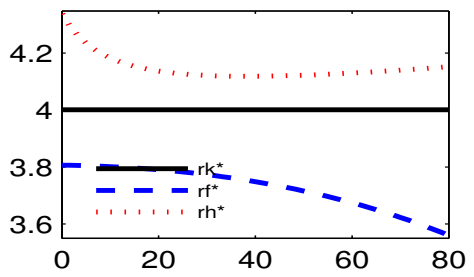

Prices

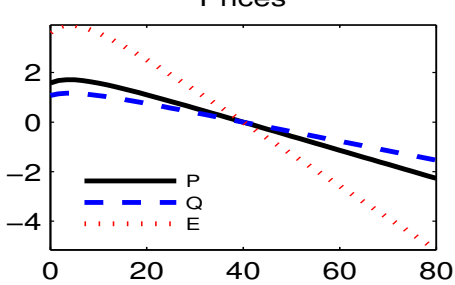

GDP and Real Exchange Rate
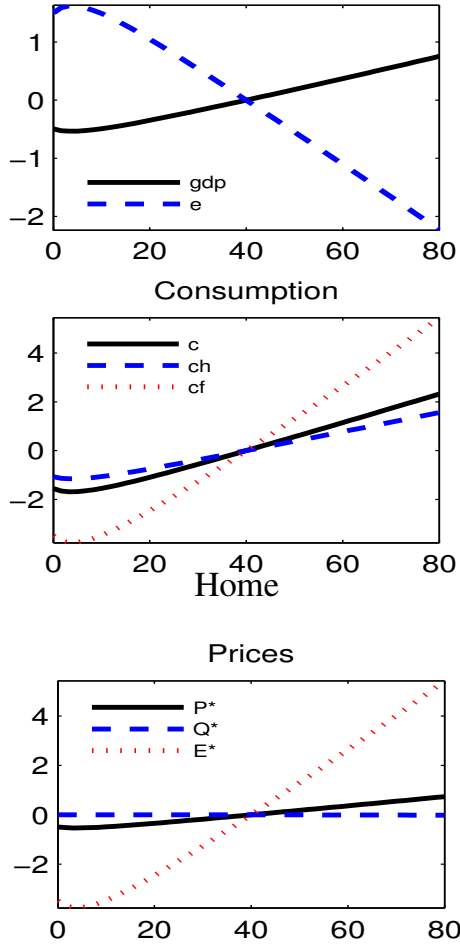

GDP and Real Exchange Rate
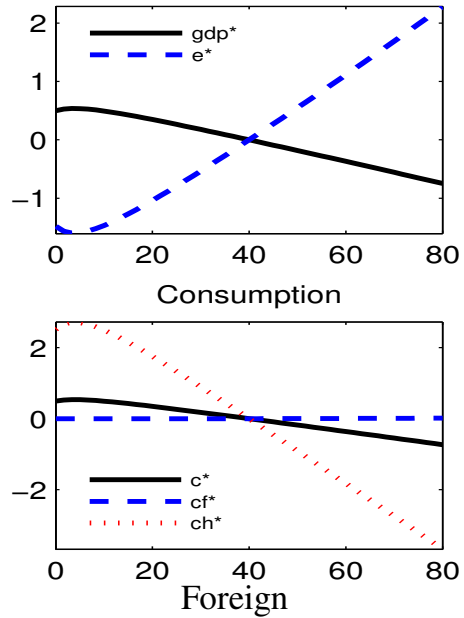

$\mathrm{H}-$ Bonds held by $\mathrm{H}-\mathrm{HH}$

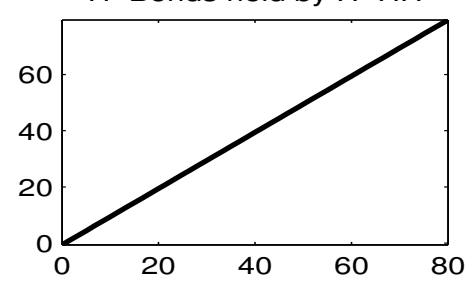

$\mathrm{H}-\mathrm{Ccy}$ Private Bonds

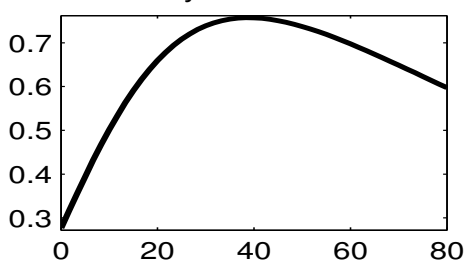

F-Ccy Private Bonds

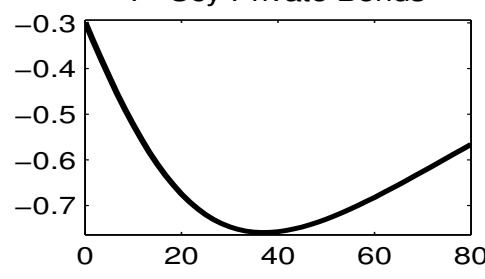

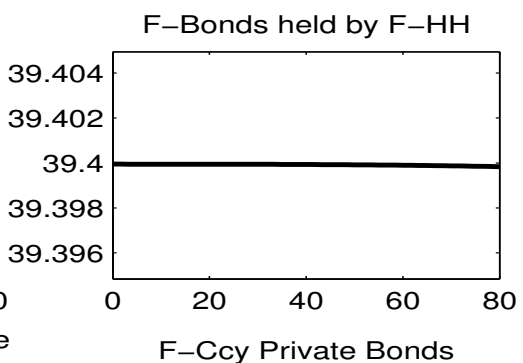
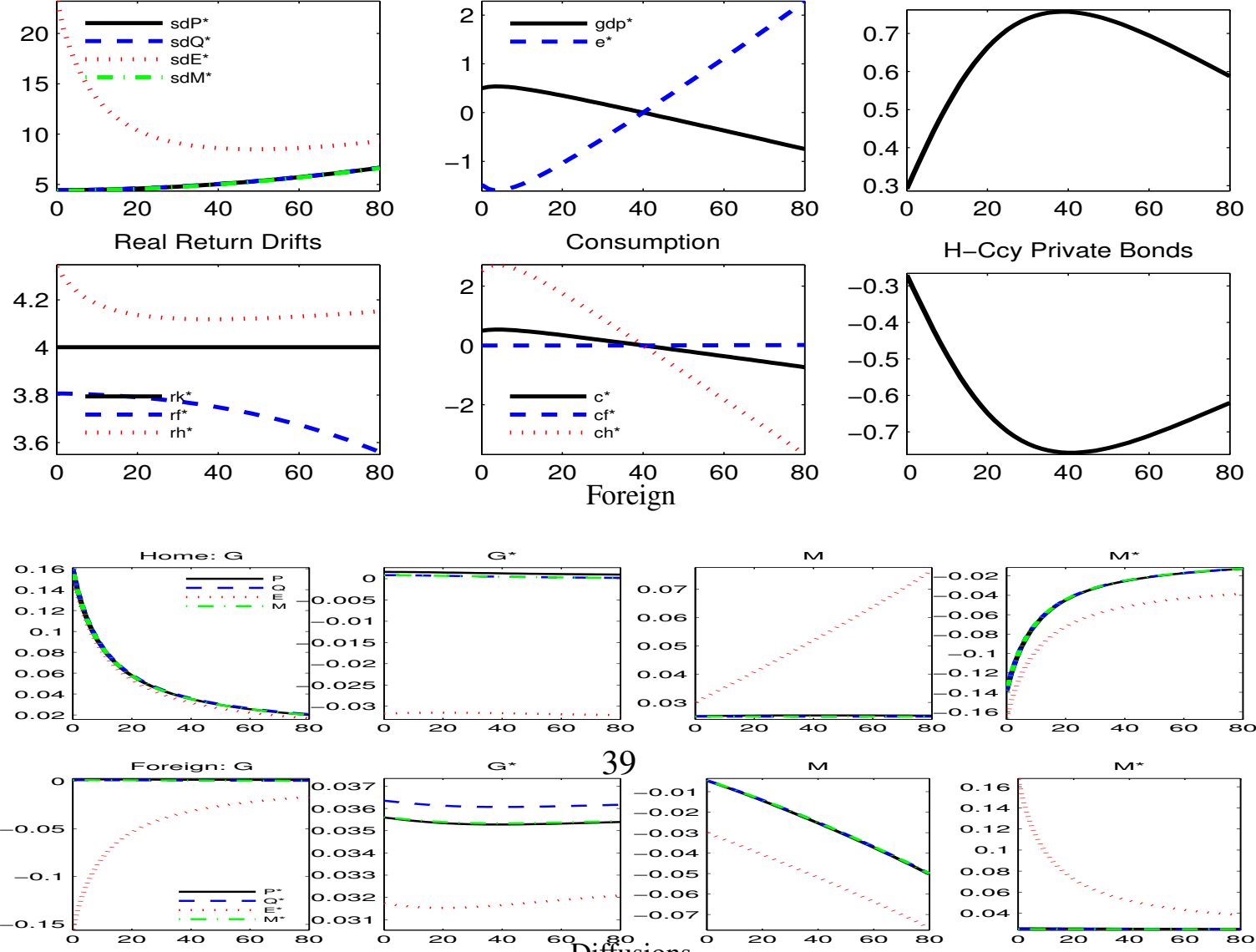

Figure 4: Effects of Government Debt 
Nominal Interest Rates
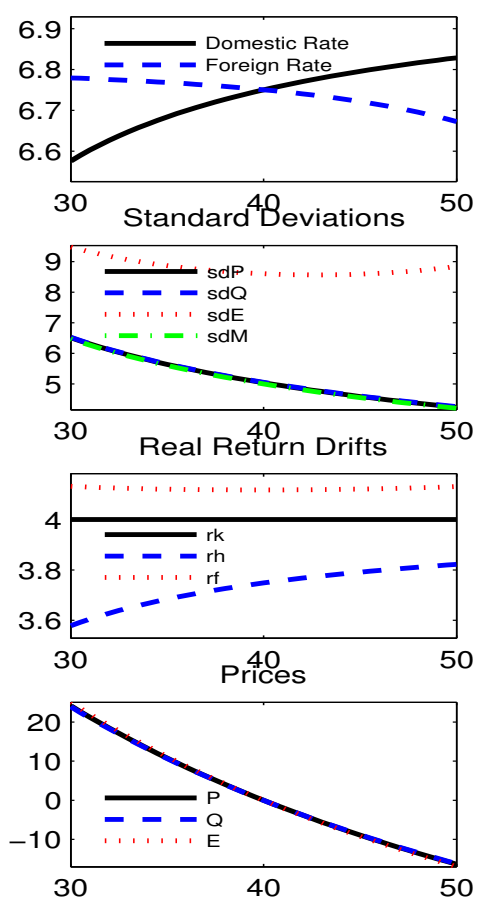

Nominal Interest Rates
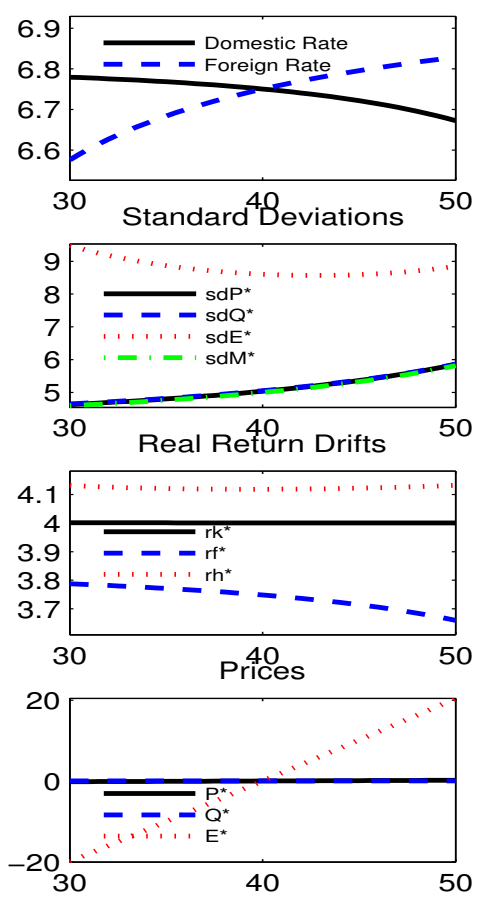

GDP and Real Exchange Rate
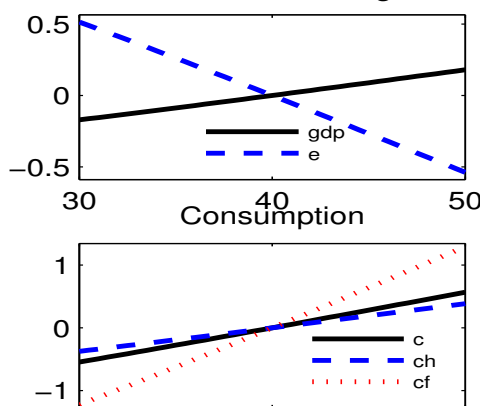

30 inter-Governmental Positions
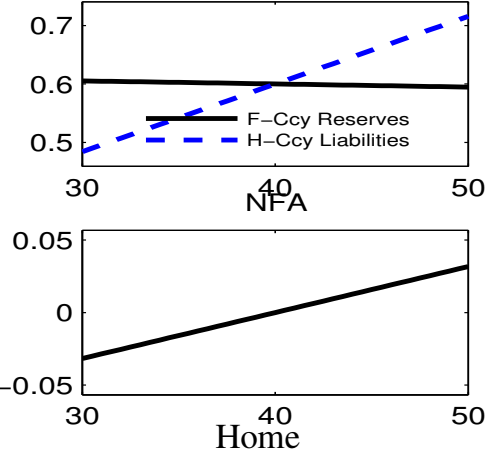

GDP and Real Exchange Rate
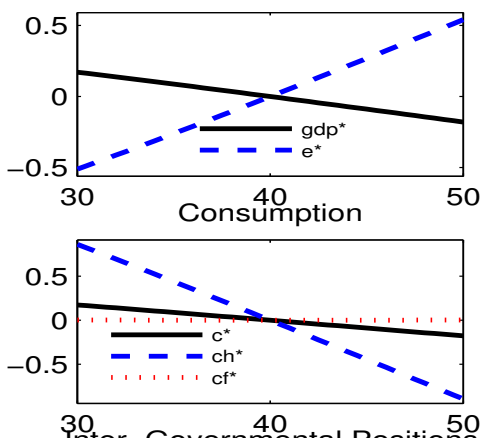

30 inter-Governmental Positions
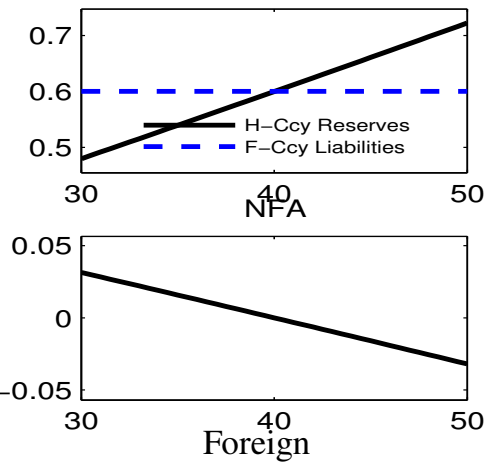

Money
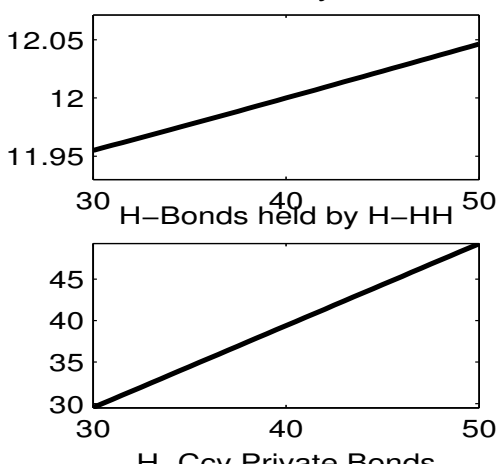

$\mathrm{H}-\mathrm{Ccy}$ Private Bonds
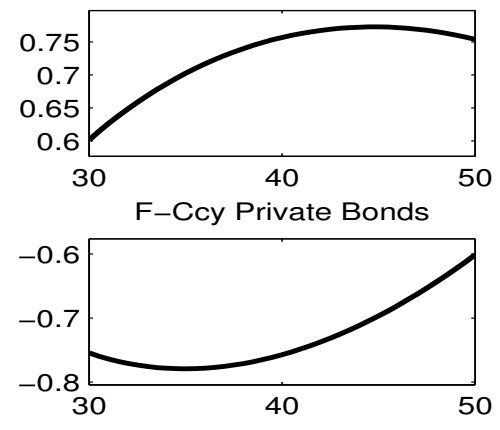

$$
0
$$
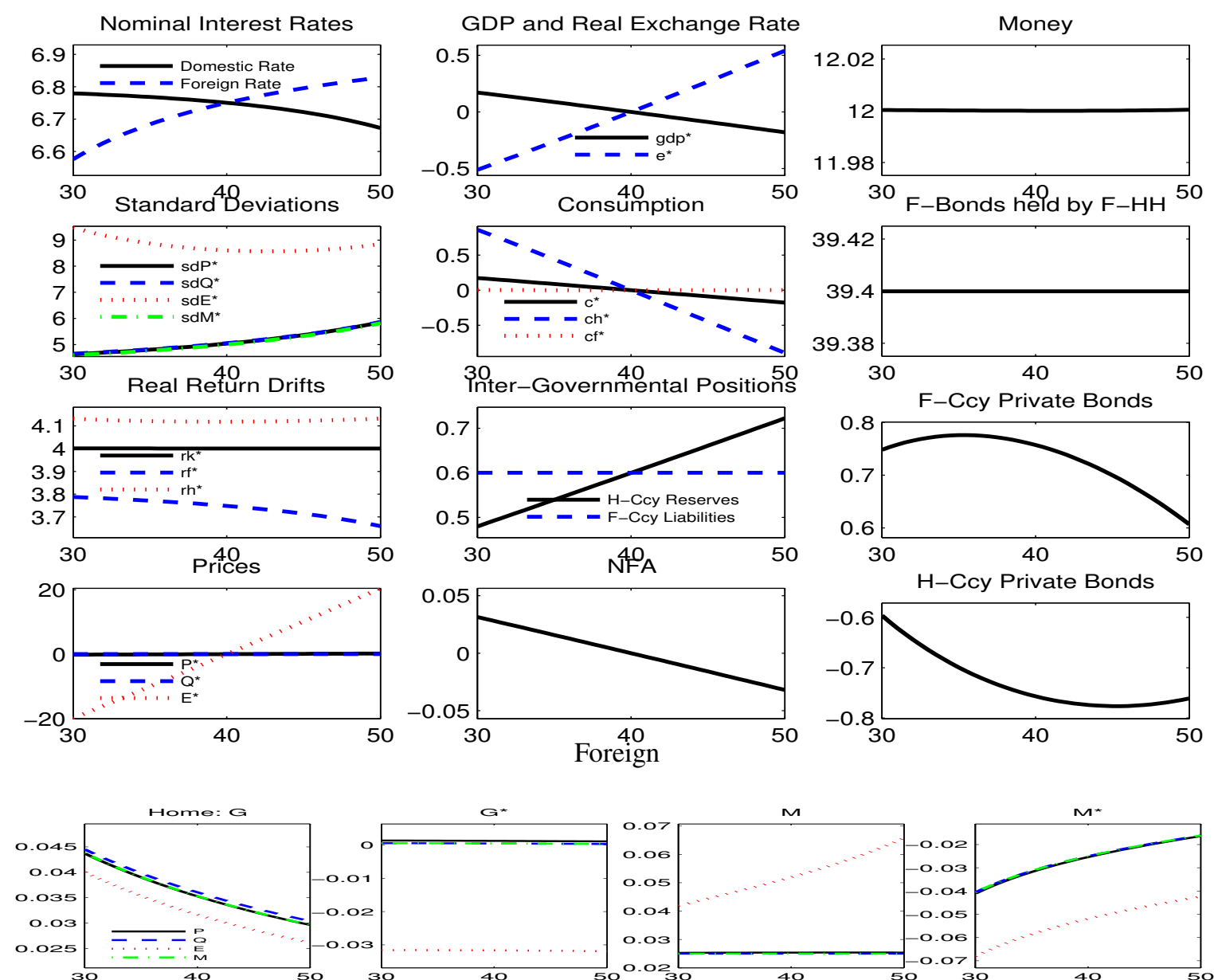

$G^{*}$
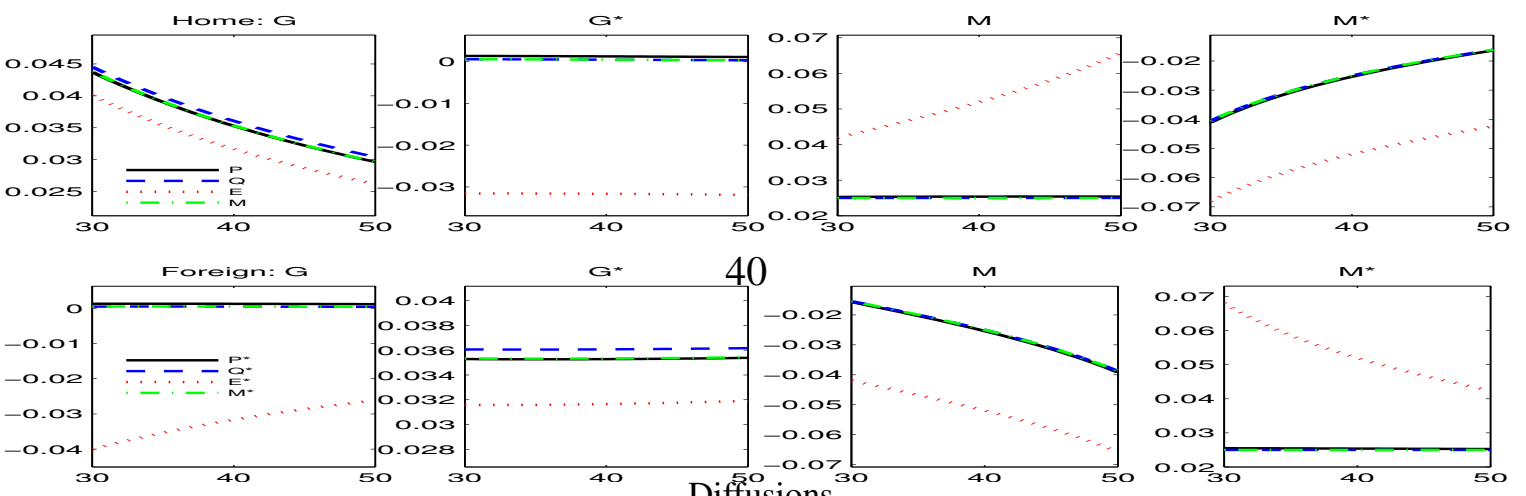

Diffusions

Figure 5: Home Open Market Operations 